\title{
Field inter-comparison of eleven atmospheric ammonia measurement techniques
}

\author{
K. von Bobrutzki ${ }^{1,2}$, C. F. Braban ${ }^{1}$, D. Famulari ${ }^{1}$, S. K. Jones ${ }^{1}$, T. Blackall ${ }^{3}$, T. E. L. Smith ${ }^{3}$, M. Blom ${ }^{4}$, H. Coe ${ }^{5}$, \\ M. Gallagher ${ }^{5}$, M. Ghalaieny ${ }^{5}$, M. R. McGillen ${ }^{5}$, C. J. Percival ${ }^{5}$, J. D. Whitehead ${ }^{5}$, R. Ellis $^{6}$, J. Murphy ${ }^{6}$, A. Mohacsi ${ }^{7}$, \\ A. Pogany ${ }^{8}$, H. Junninen ${ }^{9}$, S. Rantanen ${ }^{9}$, M. A. Sutton ${ }^{1}$, and E. Nemitz ${ }^{1}$ \\ ${ }^{1}$ Centre for Ecology and Hydrology (CEH) Edinburgh, Bush Estate, Penicuik, EH26 0QB, UK \\ ${ }^{2}$ Leibniz-Institute for Agricultural Engineering, Potsdam, Germany \\ ${ }^{3}$ Department of Geography, King's College London, London, UK \\ ${ }^{4}$ Energy Research Foundation of the Netherlands, Petten, The Netherland \\ ${ }^{5}$ School of Earth, Atmospheric and Environmental Science, University of Manchester, Manchester, UK \\ ${ }^{6}$ Department of Chemistry, University of Toronto, Toronto, Canada \\ ${ }^{7}$ Research Group on Laser Physics of the Hungarian Academy of Sciences, Budapest, Hungary \\ ${ }^{8}$ Department of Optics and Quantum Electronics, University of Szeged, Szeged, Hungary \\ ${ }^{9}$ Department of Physics, University of Helsinki, Helsinki, Finland
}

Received: 2 July 2009 - Published in Atmos. Meas. Tech. Discuss.: 4 August 2009

Revised: 14 January 2010 - Accepted: 15 January 2010 - Published: 27 January 2010

\begin{abstract}
Eleven instruments for the measurement of ambient concentrations of atmospheric ammonia gas $\left(\mathrm{NH}_{3}\right)$, based on eight different measurement methods were intercompared above an intensively managed agricultural field in late summer 2008 in Southern Scotland. To test the instruments over a wide range of concentrations, the field was fertilised with urea midway through the experiment, leading to an increase in the average concentration from 10 to $100 \mathrm{ppbv}$. The instruments deployed included three wetchemistry systems, one with offline analysis (annular rotating batch denuder, RBD) and two with online-analysis (Annular Denuder sampling with online Analysis, AMANDA; AiRRmonia), two Quantum Cascade Laser Absorption Spectrometers (a large-cell dual system; DUAL-QCLAS, and a compact system; c-QCLAS), two photo-acoustic spectrometers (WaSul-Flux; Nitrolux-100), a Cavity Ring Down Spectrosmeter (CRDS), a Chemical Ionisation Mass Spectrometer (CIMS), an ion mobility spectrometer (IMS) and an OpenPath Fourier Transform Infra-Red (OP-FTIR) Spectrometer. The instruments were compared with each other and with the average concentration of all instruments. An overall good agreement of hourly average concentrations between the instruments $\left(R^{2}>0.84\right)$, was observed for $\mathrm{NH}_{3}$ concentrations at the field of up to $120 \mathrm{ppbv}$ with the slopes against the
\end{abstract}

Correspondence to: E. Nemitz (en@ceh.ac.uk) average ranging from 0.67 (DUAL-QCLAS) to 1.13 (AiRRmonia) with intercepts of $-0.74 \mathrm{ppbv}$ (RBD) to $+2.69 \mathrm{ppbv}$ (CIMS). More variability was found for performance for lower concentrations $(<10 \mathrm{ppbv})$. Here the main factors affecting measurement precision are (a) the inlet design, (b) the state of inlet filters (where applicable), and (c) the quality of gas-phase standards (where applicable). By reference to the fast $(1 \mathrm{~Hz})$ instruments deployed during the study, it was possible to characterize the response times of the slower instruments.

\section{Introduction}

Ammonia $\left(\mathrm{NH}_{3}\right)$ plays an important role in atmospheric chemistry. It represents the major alkaline gas and is therefore important for the neutralization of acidic gases and the formation of particulate matter (Duyzer et al., 1994; Asman et al., 1998). Deposition of atmospheric $\mathrm{NH}_{3}$ to ecosystem can lead to effects such as eutrophication and acidification of soils, contributing to forest decline and a decrease in biological diversity (Fangmeier et al., 1994; Sutton et al., 1995; Ferm, 1998). As a consequence, many measurement methods for $\mathrm{NH}_{3}$ have been developed. Ambient measurement of $\mathrm{NH}_{3}$ concentrations is difficult due to several factors: ambient levels vary widely, from $5 \mathrm{pptv}$ in remote regions (Janson et al., 2001; Sutton et al., 2001) to $500 \mathrm{ppbv}$

Published by Copernicus Publications on behalf of the European Geosciences Union. 
near sources (Krupa, 2003). Ammonia occurs in gaseous, particulate and liquid phases which add further complexity to its measurement (Warneck, 1988), since the measurement technique should be specific to the gas-phase and not modify the gas-aerosol equilibrium which depends on environmental conditions (Mozurkewich, 1993). In addition, $\mathrm{NH}_{3}$ is "sticky" and interacts with surfaces of materials, often leading to slow inlet response times (Yokelson et al., 2003). Finally, $\mathrm{NH}_{3}$ is emitted by people, increasing the potential for sample contamination (Sutton et al., 2000b).

Currently, bulk denuder techniques are the most widely used method for sampling $\mathrm{NH}_{3}$ and operate by stripping the gas phase $\mathrm{NH}_{3}$ from the air stream (Ferm, 1979; Keuken et al., 1988). The main disadvantages of this manual sampling method are the low temporal-resolution, and when highfrequency measurements (e.g. hourly) are needed, the manpower required becomes considerable. Moreover, the manual handling, including sample preparation, wet-chemical analysis and sample storage, increase the chances of sample contamination. In the 1980s systems were developed, based on wet effluent diffusion denuder (WEDD) techniques, to collect stripping solution at regular intervals into test tubes (e.g. Keuken et al., 1988), this automated the process of sample preparation and extraction, while still retaining the need for manual off-line analysis. In a next step, in the 1990s these WEDDs and mist chambers were coupled to $\mathrm{NH}_{4}^{+}$online analysers in the field (Simon et al., 1991; Simon and Dasgupta, 1993; Wyers et al., 1993; Blatter et al., 1994; Erisman et al., 2001).

In parallel, spectroscopic techniques for $\mathrm{NH}_{3}$ were developed, such as the use of chemiluminescence $\mathrm{NO}_{\mathrm{x}}$ monitors with $\mathrm{NH}_{3}$ converters (e.g. Breitenbach and Shelef, 1973), Differential Optical Absorption Spectroscopy (DOAS; Gall et al., 1991), Tunable Diode Laser Absorption Spectroscopy (TDLAS; Grisar et al., 1987; Warland et al., 2001) and Fourier Transform Infra-Red spectroscopy (FTIR; Galle et al., 2000). While many of these techniques have been deployed successfully to measure concentrations and emissions downwind of strong sources, it has only been over the past 15 years that spectroscopic techniques have gradually become sufficiently sensitive and robust for field application at typical ambient concentrations ( 0.1 to $10 \mathrm{ppbv})$. Approaches more recently applied for $\mathrm{NH}_{3}$ measurements include photoacoustic spectroscopy (e.g. Harren et al., 2000; Pushkarsky et al., 2002), Chemical Ionization Mass Spectrometry (CIMS; e.g. Norman et al., 2007; Nowak et al., 2007), quantum cascade laser absorption spectrometers (QCLAS; e.g. McManus et al., 2002) and Ion Mobility Spectrometry (IMS; e.g. Myles et al., 2006).

Some experiments have been carried out to compare $\mathrm{NH}_{3}$ measurement techniques. Wiebe et al. (1990) reported a test of four methods: FTIR, filter-pack, denuders (simple and annular) and a transition flow reactor. Williams et al. (1992) conducted an inter-comparison of five instruments: a photofragmentation/laser-induced fluorescence
(PF/LIF) instrument, a molybdenum oxide annular denuder sampling/chemiluminescence detection (MOADS) system, a tungsten oxide denuder sampling/chemiluminescence detection (DARE) system, a method based on citric acid coated denuder sampling coupled with ion chromatographic analysis (CAD/IC), and a method using an oxalic acid coated filter pack sampling coupled with colorimetric analysis (FP/COL). For selection within the Netherlands National Air Quality Monitoring Network (NAQMN) six analysers were studied by Mennen et al. (1996): a wet-annular rotating denuder, a $\mathrm{WO}_{3}$-coated thermodenuder, a $\mathrm{V}_{2} \mathrm{O}_{5}$-coated thermodenuder, a DOAS system, a photoacoustic monitor and a chemiluminescence $\mathrm{NO}_{\mathrm{x}}$ monitor with $\mathrm{NH}_{3}$ converter. In addition, there were smaller inter-comparisons between two instruments: a field study on Tenerife by Milford et al. (2000) included an AMANDA instrument (see below) and a diffusion scrubber flow injection analyzer (DS-FIA). Fehsenfeld et al. (2002) reported a comparison of a CIMS with a citric acid denuder and a molybdenum oxide $\left(\mathrm{MoO}_{\mathrm{x}}\right)$ converter. Nowak et al. (2006) compared two different CIMS instruments in the field: a NOAA chemical Science Division (NOAA-CSD) apparatus and the Georgia tech (GT) low pressure reactor.

The development of new continuous measurement approaches has motivated two major inter-comparison campaigns in recent years: a laboratory inter-comparison of gaseous $\mathrm{NH}_{3}$ with seven instruments were performed by Schwab et al. (2007): a TDLAS, a wet srubbing long-path absorption spectrometer (LOPAP), a WEDD system, an IMS, a photo-acustic absorption analyzer, and a modified chemiluminescence analyzer. The emphasis of this short intercomparison was on the accuracy and time-response of these approaches under laboratory conditions while sampling from a common manifold. In addition, Norman et al. (2009) realised an inter-comparison of three instruments at a Swiss grassland site: a modified Proton Transfer reaction Mass Spectrometer (PTR-MS; Norman et al., 2007) and two wet chemistry techniques, based on a horizontal denuder technique (GRAEGOR; Thomas et al., 2009), and a diffusion membrane sampler (AiRRmonia; Erisman et al., 2001). Further, Whitehead et al. (2008) made measurements between a QCLAS, a TDLAS and an AMANDA instrument.

The work presented here included eight different atmospheric $\mathrm{NH}_{3}$ measurement methods implemented in eleven different instruments, focussing on comparison of the techniques under typical field conditions. Ammonia was measured over intensively managed grassland in Scotland, between 20 August and 4 September 2008. The field was fertilised on 28 August 2008 to stimulate emission from the field and test the instrumentation over a wide concentration range, including regimes that are typical for moderately agricultural mixed land use and also near-sources. The aim was to assess instrument performance and characterise the instrument response times. In addition to the description of time-series, we used regression analyses for concentrations over the entire 


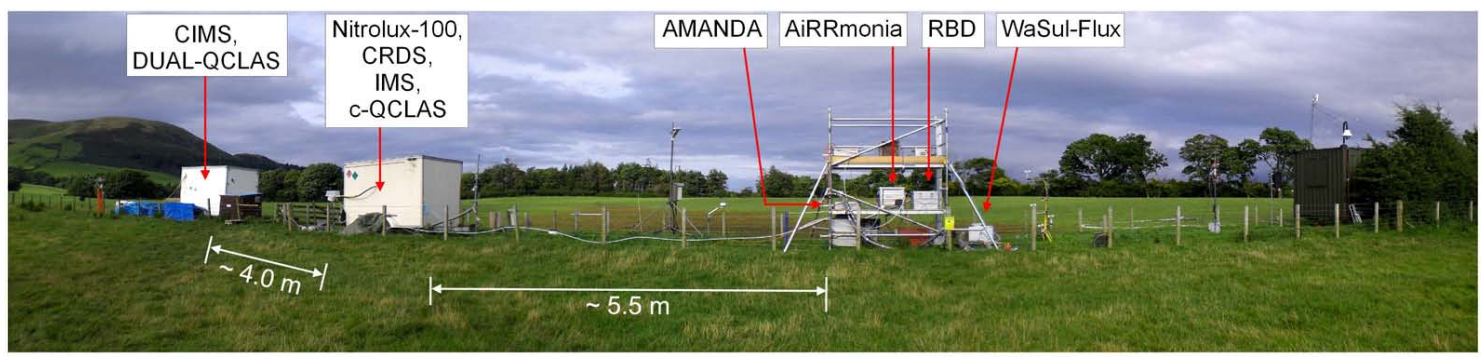

Fig. 1. Intensively managed grassland site (Easter Bush) with instruments, looking from the S field towards the $\mathrm{N}$ field.

concentration range and, separately, below $10 \mathrm{ppbv}$ to assess the performance at low concentrations in more detail. Three of the instruments were also used for micrometeorological flux measurements based either on the flux gradient technique (AMANDA, WaSul-Flux) or eddy-covariance (DUALQCLAS), but these results will be presented elsewhere.

\section{Methodology}

\subsection{Site description}

The measurements were made at a micrometeorological field

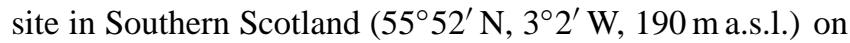
an intensively managed grassland area (Easter Bush), located about $1 \mathrm{~km}$ to the west of the Pentland Hills with peaks of up to $500 \mathrm{~m}$ (see Milford et al., 2001; Whitehead et al., 2008). The Easter Bush site is divided into two fields, each approximately 5 ha, more than $90 \%$ of which is covered by Lolium perenne (perennial ryegrass). The dividing line between the fields runs NW to SE, and in the following analysis the fields to the NE and SW of the measurement equipment are referred to as $\mathrm{N}$ field and $\mathrm{S}$ field, respectively. The Pentland Hills channel the wind so that on average $60 \%$ of the wind comes clearly from the S field and 19\% clearly from the $\mathrm{N}$ field (Milford et al., 2001). Both fields receive the same management and have been used for cattle and sheep grazing in recent years. Easter Bush is an intensive flux monitoring site of the NitroEurope IP measurement programme (Sutton et al., 2007) and has hosted several studies on $\mathrm{NH}_{3}$ flux measurements (Milford et al., 2001; Whitehead et al., 2008). The inter-comparison experiment took place from 20 August to 4 September 2008 with the instruments placed along the boundary between the two fields (Fig. 1). All instruments were deployed with an inlet height of $1.1 \mathrm{~m}$ above ground, with the exception of the DUAL-QCLAS $(1.95 \mathrm{~m})$, as this was also used for eddy-covariance flux measurements.

Fertilisation took place on 28 August 2008 on both the $\mathrm{N}$ and $\mathrm{S}$ field, with $35 \mathrm{~kg} \mathrm{~N} \mathrm{ha}^{-1}$ in the form of urea.

\subsection{Environmental conditions during the field experiment}

Figure 2 presents the time-series of hourly data of precipitation, temperature and relative humidity. The wind direction and speed are represented by the direction and length of the arrows, respectively. The mean wind speed was around $3 \mathrm{~m} \mathrm{~s}^{-1}$. Several rain events occurred during the campaign with the maximum amount being $4.9 \mathrm{~mm} \mathrm{~h}^{-1}$ on $20 \mathrm{Au}-$ gust 2008. There was no rain during the fertilisation on 28 August 2008 and therefore no $\mathrm{NH}_{3}$ was washed into the ground immediately after fertilisation (see Sect. 3.1). The relative humidity never decreased below $58 \%$. The mean temperature was $12.8^{\circ} \mathrm{C}$. Overall, August 2008 was wet in Eastern Scotland, receiving about twice as much rainfall compared with the long-term average (mean since 1961; values for Leuchars; Eden, 2008). This high level of precipitation led to the formation of a "pond" near to the measurement site in the $\mathrm{N}$ field. Although the accumulating water was pumped away on several occasions, the associated rotting vegetation is likely to have created an additional and heterogeneous $\mathrm{NH}_{3}$ source near the instruments, for $\mathrm{NE}$ wind directions. The few occurrences of this wind direction were therefore excluded from the regression analysis presented below.

Figure 2 also includes a time-series of $\mathrm{NH}_{4}^{+}$aerosol in $\mathrm{PM}_{2.5}$ measured with a MARGA instrument, similar to GRAEGOR (Thomas et al., 2009), except that it deploys online cation analysis rather than FIA and a $\mathrm{PM}_{2.5}$ inlet cyclone, at the Auchencorth EMEP site, $10 \mathrm{~km}$ south of Easter Bush. From previous simultaneous measurements, there is close $( \pm 20 \%)$ agreement between $\mathrm{NH}_{4}^{+}$concentrations at Auchencorth and Easter Bush. This time-series is included because it is possible that some of the $\mathrm{NH}_{3}$ measurement techniques deployed here may show some cross-sensitivity to $\mathrm{NH}_{4}^{+}$aerosol. Ammonium concentrations were below $1 \mu \mathrm{g} \mathrm{m}^{-3}$ except for 30 and 31 August 2008.

\subsection{Measurement techniques}

The characteristics of the $\mathrm{NH}_{3}$ measurement systems deployed in the inter-comparison are summarised in Table 1, and can be described as followed. 


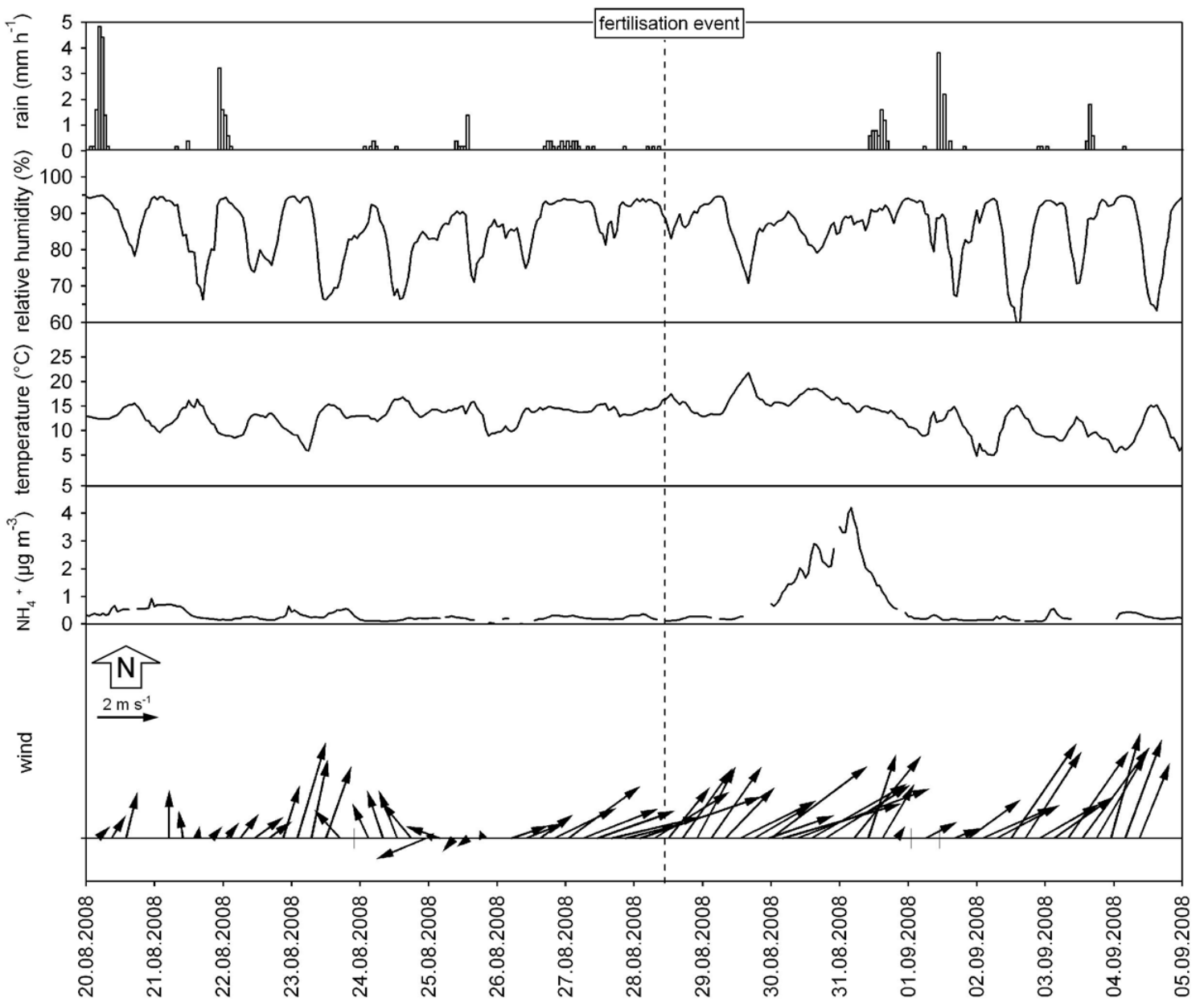

Fig. 2. Time-series of hourly data from selected meteorological variables during the campaign. The aerosol $\mathrm{NH}_{4}^{+}$concentration was measured using a MARGA monitor (see text) at the Auchencorth EMEP site, $10 \mathrm{~km}$ south of the Easter Bush field site. The wind panels show both magnitude and direction.

\subsubsection{Wet-chemistry analysers}

Two of three wet chemistry instruments deployed (RBD, AMANDA) are based on the denuder principle described by Ferm (1979), whereby gas phase $\mathrm{NH}_{3}$ is stripped from the air stream through diffusion to the denuder glass walls, without collecting the $\mathrm{NH}_{4}^{+}$aerosol phase, since gas molecules diffuse quicker than particles to a moistened/acidified tube wall. In a third instrument (AiRRmonia), a diffusion membrane was used to strip the gas phase from the air stream. All three instruments were developed by the Energy Research Foundation of the Netherlands (ECN, Petten, NL). The instruments were housed in weather proof enclosures and placed at the measurement height, with inlets of $<0.1 \mathrm{~m}$ length.

\section{Annular rotating batch denuder (RBD)}

In the RBD instrument (Keuken et al., 1988), air is pumped at $271 \mathrm{~min}^{-1}$ through the annulus formed by two horizontal concentric rotating glass tubes (with a diameter of $45 \mathrm{~mm}$ ) and a $25 \mathrm{~cm}$ long HDPE (High Density Polyethylene) inlet (12 $\mathrm{mm}$ diameter). The glass tubes are wetted with a thin layer of collecting liquid, which contains $2.0 \mathrm{~g}^{-1} \mathrm{NaOH}$, $3.4 \mathrm{ml}^{-1}>98 \%$ formic acid and $0.5 \mathrm{mg} \mathrm{l}^{-1}$ thymol as biocide. Ammonia is absorbed into this thin layer of collection solution over a sampling time of $40 \mathrm{~min}$ within each hour, after which the sample (10 to $15 \mathrm{ml}$ ) is pumped off to an autosampler holding $20 \mathrm{ml}$ test tubes. All samples were analysed for $\mathrm{NH}_{4}^{+}$offline on an $\mathrm{NH}_{3}$ Flow Injection Analyser (AMFIA, ECN, Petten, NL), based on analysis by selective ion membrane and conductivity measurement (Genfa and Dasgupta, 2000). For analysis, 0.5 M NaOH solution is added to the sample, resulting in the conversion of $\mathrm{NH}_{4}^{+}$to gas-phase $\mathrm{NH}_{3}$ (g) in solution. As the solution then passes a semi-permeable Teflon membrane, $\mathrm{NH}_{3(\mathrm{~g})}$ permeates the membrane and is dissolved in a counter stream of deionised water. Here $\mathrm{NH}_{3}$ is re-ionised to $\mathrm{NH}_{4}^{+}$and is detected by conductivity (Sutton et al., 2000a; Erisman et al., 2001; Milford et al., 2001). This technique is precise 
Table 1. Summary of the characteristics of the instruments.

\begin{tabular}{|c|c|c|c|c|c|c|}
\hline Instrument & Manufacturer & $\begin{array}{l}\text { Air flow } \\
\text { rate } \\
{\left[1 \mathrm{~min}^{-1}\right]}\end{array}$ & $\begin{array}{l}\text { Used time } \\
\text { resolution/used } \\
\text { time average [s] }\end{array}$ & $\begin{array}{l}\text { Precision } \\
\text { [ppbv] }\end{array}$ & $\begin{array}{l}\text { Range } \\
\text { [ppbv] }\end{array}$ & $\begin{array}{l}\text { Accuracy } \\
{[\%]}\end{array}$ \\
\hline RBD & $\begin{array}{l}\text { Energy Research } \\
\text { Foundation of the } \\
\text { Netherlands (ECN) } \\
\text { (Keuken et al., 1988) }\end{array}$ & 27 & $2400 / 3600$ & 0.02 & not specified & not specified \\
\hline AMANDA & $\begin{array}{l}\text { Energy Research } \\
\text { Foundation of the } \\
\text { Netherlands (ECN) } \\
\text { (Wyers et al., 1993) }\end{array}$ & 28 & $450 / 450$ & 0.02 & $0.02-500$ & not specified \\
\hline AiRRmonia & $\mathrm{R} \& \mathrm{R}$ Mechatronics & 1 & $600 / 60$ & 0.05 & $0.04-500$ & $\pm 3^{1}$ \\
\hline DUAL-QCLAS & $\begin{array}{l}\text { Aerodyne Research, } \\
\text { Inc. (ARI) } \\
\text { (Whitehead et al., 2008) }\end{array}$ & 15 & $0.2 / 60$ & 0.018 & not specified & $\pm 5^{2}$ \\
\hline c-QCLAS & $\begin{array}{l}\text { Aerodyne Research, } \\
\text { Inc. (ARI) } \\
\text { (McManus et al., 2007) }\end{array}$ & 8.9 & $1 / 60$ & 0.05 & not specified & $\pm 10^{1}$ \\
\hline WaSul-Flux & Hilase Ltd. & 4 & $\begin{array}{l}300-1800 / \\
300-1800\end{array}$ & 0.25 & $0.25-1000000$ & not specified \\
\hline Nitrolux-100 & $\begin{array}{l}\text { Pranalytica Inc. } \\
\text { (Cowen et al., 2004) }\end{array}$ & $1.2-1.6$ & $3 / 300$ & 0.1 & $0.1-200$ & $\pm 4^{3}$ \\
\hline CRDS & $\begin{array}{l}\text { Enviro Sense } 1000 \\
\text { Analyzer, Picarro } \\
\text { (Berden et al., 2000) }\end{array}$ & 1 & $3 / 300$ & 0.07 & $0.07-25$ & $\pm 7^{3}$ \\
\hline CIMS & $\begin{array}{l}\text { Georgia Institute of } \\
\text { Technology CIMS team } \\
\text { (Nowak et al., 2007) }\end{array}$ & 19.5 & $1 / 60$ & 0.94 & not specified & $\pm 4^{4}$ \\
\hline IMS & Bruker Daltonik & 0.4 & $4 / 60$ & not specified & $\begin{array}{l}\text { Variable, } \\
\text { dependent on } \\
\text { other substances } \\
\text { present }\end{array}$ & not specified \\
\hline OP-FTIR & MIDAC Corp. & $\mathrm{n} / \mathrm{a}$ & $8 / 120$ & not specified & not specified & not specified \\
\hline
\end{tabular}

1 based on manufacturer specification

2 based on the statistical standard deviations of the reported mixing ratios during calibration

3 based on the statistical standard deviations (twice) of hourly data, referenced against AiRRmonia inter-comparison dataset

4 based on the calibration during the experiment

and reasonably specific, but it has been shown to be somewhat cross-sensitive to selected amines at high concentrations (Husted et al., 2000). In addition to $\mathrm{NH}_{3}$ it is possible to use the RBD to capture other water soluble inorganic trace gases like $\mathrm{HNO}_{3}, \mathrm{HCl}, \mathrm{SO}_{2}$ and $\mathrm{H}_{2} \mathrm{O}_{2}$ (Keuken et al., 1988), which would need to be quantified by a different analytical technique such as anion chromatography.

\section{AMANDA}

The technique of $\mathrm{NH}_{3}$ Measurement by ANnular Denuder sampling with online Analysis (AMANDA) was developed by Wyers et al. (1993). The system used here consists of three annular wet rotating denuder inlets, similar to that used in the RBD, located at different heights $(0.39 \mathrm{~m}, 1.07 \mathrm{~m}$, and $2.20 \mathrm{~m})$. Unlike in the RBD, however, the stripping solution $\left(0.5 \mathrm{~g} \mathrm{l}^{-1} \mathrm{NaHSO}_{4}\right.$ containing $0.2 \mathrm{mll}^{-1} 37 \% \mathrm{HCHO}$ 
as a biocide) is continuously pumped from the denuders to a common detector block, where the three concentrations are analysed sequentially by the same selective ion membrane/conductivity technique as deployed in the AMFIA. In the denuders a constant liquid level is maintained by the use of an independent peristaltic pump, controlled by a conductivity measurement along the denuder. This particular instrument has been upgraded with a newer detection block, using two conductivity measurements. One conductivity cell monitors the initial conductivity of the deionised water, while a second conductivity cell monitors the $\mathrm{NH}_{4}^{+}$content after the membrane exchange. The difference in both readings of the conductivity cells is a measure for the original $\mathrm{NH}_{3}$ content in the sampled air. This approach takes into account changes in the water quality during longer service intervals. The instrument reports one concentration gradient every $7.5 \mathrm{~min}$, but the overall instrument response time is limited by the exchange of the stripping solution within the denuder (see Sect. 3.3 below).

\section{AiRRmonia}

The AiRRmonia is a further development of the AMANDA technique. As with the AMANDA, it was originally developed by ECN (Energy Research Centre of the Netherlands, Petten, NL), but has been further improved and commercialised (Mechatronics Instruments b.v., Hoorn, NL) to provide a sensitive, easy-to-use $\mathrm{NH}_{3}$ monitor (Erisman et al., 2001). Unlike the RBD and AMANDA, the instrument uses a Teflon membrane to strip the $\mathrm{NH}_{3}$ from the airflow into a deionised water flow. The detection system of $\mathrm{NH}_{3}$ is similar to that of the AMANDA, also using the double conductivity measurement. Precision and stability of this instrument are further improved through the use of syringe pumps for reagents and solutions, which undergo less variation due to changes in pump tubing and temperature than the peristaltic pumps used in the AMANDA. The AiRRmonia inlet consists of stainless steel with a length of $5 \mathrm{~cm}$ and a diameter of $3.2 \mathrm{~mm}$.

\subsubsection{Quantum cascade laser absorption spectroscopy (QCLAS)}

QCLAS is an infrared absorption technique that makes use of the rich spectral absorption region in the mid-infrared, in which most species of interest in the atmosphere have resolvable absorption features. Both laser systems used here were produced by Aerodyne Research Inc. (Billerica, MA, USA), and operate with the light source of a thermoelectrically cooled pulsed Quantum Cascade (QC) laser (Alpes Lasers, Neuchatel, Switzerland). Their design was similar to the closed path configuration described by McManus et al. (2002). These lasers scan over a narrow range of wave numbers chosen to contain an absorption feature of the trace gas of interest, which for $\mathrm{NH}_{3}$ is at a wavelength of $10.3 \mu \mathrm{m}$.
Both instruments use astigmatic Herriott multipass absorption cells, to increase the effective path length, while providing a fast spot measurement. They operate at cell pressures of around 40 Torr as a balance between minimising line broadening, maximising time response and achieving good sensitivity.

In the data acquisition protocol chosen for this study, the spectra were recorded and averaged over the data acquisition time of one second, with the resulting spectra fitted to known spectral line profiles from the HITRAN (HIgh-resolution TRANsmission) molecular spectroscopic database (Rothmann et al., 1998). In principle, this approach provides an absolute measurement.

\section{DUAL-QCLAS}

The DUAL-QCLAS uses two separate thermoelectrically cooled pulsed Quantum Cascade (QC) lasers for the potential measurement of two trace gases at different wave lengths. The two beams are brought together (with the pulses separated in time) and directed into either one of two astigmatic Herriott multipass absorption cells where they undergo 238 reflections, before leaving the cell and arriving at a cryogenically cooled $\mathrm{HgCdTe}$ infrared detector. The large (51) cell provides an effective path length of $210 \mathrm{~m}$, while the small $(0.31)$ cell provides a path length of $56 \mathrm{~m}$. The large cell is used for higher precision measurement applications whilst the small cell (used here) provides the fast time response required for eddy-covariance flux measurements. Data were recorded at a rate of $5 \mathrm{~Hz}$ to be averaged up in post-processing for the purpose of the concentration intercomparison reported here. Background measurements were made typically every $15 \mathrm{~min}$ and background spectra were subtracted from the measurements prior to the wave fit. For this purpose, $\mathrm{NH}_{3}$ free air was generated using a customized $\mathrm{Pd} / \mathrm{AL}_{2} \mathrm{O}_{3}$ catalyst heated to $300^{\circ} \mathrm{C}$, in an attempt to determine the background at a relative humidity as close to ambient as possible. The $\mathrm{Pd} / \mathrm{AL}_{2} \mathrm{O}_{3}$ catalyst has been shown to have a negligible affect on the water concentration of the background air (Wert et al., 2002). The inlet was a $2 \mathrm{~m}$ length of $6.4 \mathrm{~mm}$ (OD) PFA tube, which was co-located with an ultrasonic anemometer (model HS; Gill Instruments Ltd., Lymington, UK) for the purpose of flux measurements. A general calibration factor of 1.23 was applied to the DUALQCLAS data based on the field based calibration. For more information and studies of the DUAL-QCLAS see Whitehead et al. (2008).

\section{Compact QCLAS (c-QCLAS)}

The c-QCLAS uses a single QC laser and a single cell with a volume of 0.51 and an effective path length of $76 \mathrm{~m}$. Air was drawn into the optical cell through a short $(<0.1 \mathrm{~m})$ quartz inlet that was heated to $40{ }^{\circ} \mathrm{C}$ and coated with a hydrophobic siloxyl coating. The inlet contains a critical orifice that drops 
the pressure in the optical cell to approximately 45 Torr while keeping a constant flow rate of approximately $91 \mathrm{~min}^{-1}$. Following the critical orifice, the flow is split into two branches with $90 \%$ of the flow making a sharp turn and being pulled through the optical cell. The other $10 \%$ is pulled directly to the pump, relying on inertia to remove more than $50 \%$ of particles larger than $300 \mathrm{~nm}$. This design was chosen to minimize surface interactions for gas phase $\mathrm{NH}_{3}$ while reducing possible positive artefacts in the measurements from particle volatilization. The quartz inlet was connected to the optical cell via $\sim 3 \mathrm{~m}$ and $9.5 \mathrm{~mm}$ PFA tubing. Background measurements were performed every $30 \mathrm{~min}$ by flushing the quartz inlet using dry nitrogen. Standard addition calibrations were performed every two hours with a permeation tube standard, added either into ambient air or dry nitrogen. The permeation rate was determined gravimetrically by the manufacturer (Kin-Tek) as $100 \mathrm{ng} \mathrm{m^{-1 }}$ at $40^{\circ} \mathrm{C}$. The rate was confirmed as $100 \pm 5 \mathrm{ng} \mathrm{m^{-1 }}$ at $40^{\circ} \mathrm{C}$ by passing a flow of permeation tube standard through citric acid filters for $24 \mathrm{~h}$, followed by extraction with deionized water and analysis using ion chromatography.

\subsubsection{Photoacoustic spectroscopy}

Two instruments measured $\mathrm{NH}_{3}$ concentration using photoacoustic spectroscopy. A light source is tuned to an absorption feature of the target species and molecules are excited to a higher quantum state. Modulating the light source results in a periodic temperature change, giving rise to a periodic pressure change that equates to an acoustic signal if the modulation frequency is in the acoustic range. The intensity of the acoustic signal, which can be detected by a sensitive microphone, is proportional to the concentration of the lightabsorbing species (Harren et al., 2000).

\section{Diode laser based photoacoustic system (WaSul-Flux)}

This new instrument combines near-infrared photoacoustic spectroscopy with pre-concentration sampling as described in more detail elsewhere (Pogány et al., 2008). The instrument is built into a $48.3 \mathrm{~cm} 6 \mathrm{U}$ temperature controlled instrument box and has an additional waterproof housing. The photoacoustic detection unit consists of a fibre-coupled DFB diode laser light source (FOL15DCWD-A82-19560-A, Furukawa Inc.) with $\sim 40 \mathrm{~mW}$ output light power at $1532 \mathrm{~nm}$, and an acoustically optimized photoacoustic cell with an electret microphone (Knowles, EK 3029) for measuring the photoacoustic signal. Ammonia is concentrated from the sampled air by a tungsten (VI) oxide coated preconcentration unit. The instrument has three gas inlets and is therefore suitable for measuring $\mathrm{NH}_{3}$ concentration at three different heights above the ground. The sampling lines were $6 \mathrm{~m}$ long Teflon tubes with $8 \mathrm{~mm}$ inner diameter, heated to $\sim 50^{\circ} \mathrm{C}$ by self-regulating heating tape and included filters which were replaced weekly. The pre-concentration time can be adjusted to match the air concentrations. Here the integration time was varied between 15 and 45 min according to the actual concentration. Before fertilization all three inlets were placed at the same height and the reported data are the averages of the three measurements. After fertilization, the inlets were operated in gradient configuration and the reported data represent the measurement of the middle height.

\section{Nitrolux-100}

The Nitrolux-100 (Pranalytica Inc., Santa Monica, CA, USA) is an ambient $\mathrm{NH}_{3}$ analyser that uses resonant photoacoustic spectroscopy and a line-tunable $\mathrm{CO}_{2}$ laser to provide continuous or on-demand measurements (Pushkarsky et al., 2003). The excited $\mathrm{NH}_{3}$ molecules undergo collisional deactivation, which converts the absorbed energy into periodic local heating at the modulation frequency of the laser. The resulting acoustic waves are detected with minimal interferences by other compounds at typical concentrations in a non-polluted atmosphere (Cowen et al., 2004). The instrument was originally developed for clean room applications in the semiconductor industry, but has been more widely used for ambient measurements. It is operated with an inlet filter to remove dust and $\mathrm{NH}_{4}^{+}$, with a manufacturer recommended lifetime of three months, while the instrument should be calibrated by the manufacturer every six months. The Nitrolux100 was calibrated just before the beginning of the intercomparison (8 August 2008). The uncertainty associated with that calibration was a zero intercept of $-0.006 \mathrm{ppbv}$, a linearity check with $R^{2}=0.999$ and a system response time (under dry conditions) of $90 \%$ in 2 min. The Nitrolux-100 was operated with a $4 \mathrm{~m}$ and $6.4 \mathrm{~mm}$ OD Teflon inlet which was insulated and heated to $\sim 35^{\circ} \mathrm{C}$. The inlet was sheltered by an inverted plastic funnel.

\subsubsection{Cavity Ring Down Spectroscopy (CRDS)}

Cavity Ring Down Spectroscopy (CRDS) is a direct absorption technique, which uses pulsed or continuous light sources and has a significant higher sensitivity than other conventional absorption spectroscopy (Berden et al., 2000). The EnviroSense 1000 Analyzer (Picarro Inc., Sunnyvale, CA, USA) monitors $\mathrm{NH}_{3}$ in air using this approach. Cavity Ring Down Spectroscopy uses a pair of mirrors facing each other. A brief pulse of laser light is injected into the cavity, and it passes back and forth between the mirrors, while a fraction leaks through the mirror. Ammonia absorbs some of the light and thus the amount of light in the cavity decreases faster-it makes fewer passes. A CRDS setup measures how long it takes for the light to drop to a certain percentage of its original intensity, and this "ringdown time" is used to calculate the concentration of the absorbing substance in the gas mixture in the cavity. Like the Nitrolux-100, the Picarro CRDS uses an inlet filter and is calibrated by the manufacturer subsequent ( $\sim 2$ months) to its most recent calibration. The 
CRDS was operated with a $4 \mathrm{~m}$ and $6.4 \mathrm{~mm}$ OD Teflon inlet which was insulated and warmed with heating tape $\left(\sim 35^{\circ} \mathrm{C}\right)$. Again, the inlet was sheltered by an inverted plastic funnel. For detailed information see Rella (2008).

\subsubsection{Chemical Ionisation Mass Spectrometry (CIMS)}

Chemical Ionisation Mass Spectrometry (CIMS) techniques use ion-molecule reactions to selectively ionize and detect trace species of interest in ambient air with high sensitivity and fast time response. The CIMS method uses a reagent ion to ionise a neutral species, and the product ion resulting from this process is identified and quantified by a quadrupole mass analyser. The distinction between chemical ionization mass spectrometry and other mass spectrometry techniques is the use of ion molecule reactions for the selective ionization of compounds of interest in the complicated matrix of ambient air. In the system deployed here, $\mathrm{NH}_{3}$ was detected using $\mathrm{H}^{+}\left(\mathrm{C}_{3} \mathrm{H}_{6} \mathrm{O}\right)_{2}$ as a reagent ion (Nowak et al., 2007). The configuration of the CIMS deployed here is described elsewhere (Slusher et al., 2004; Neuman et al., 2006; Kim et al., 2007; Nowak et al., 2007). The instrument sampled air though a $0.1 \mathrm{~m}$ long and $9.5 \mathrm{~mm}$ O.D. PFA inlet, temperature controlled to $40 \pm 1{ }^{\circ} \mathrm{C}$. Inlet flow was $19.51 \mathrm{~min}^{-1}$, with $0.881 \mathrm{~min}^{-1}$ being subsampled through a $0.65 \mathrm{~mm}$ pinhole into the ionization region, where reaction of $\mathrm{NH}_{3}$ with $\mathrm{H}^{+}\left(\mathrm{C}_{3} \mathrm{H}_{6} \mathrm{O}\right)_{2}$ proceeds. The instrumental signal was calibrated every hour using a standard addition from a calibrated permeation tube oven and an instrument background was taken hourly.

\subsubsection{Ion mobility spectrometer (IMS)}

Ion mobility spectrometers separate chemical substances on the basis of velocity of gas-phase ions in an electrical field (Eiceman and Karpas, 1994). Ions are introduced into an electrical field and the time of flight is measured. The sample molecules are first ionized by $\beta$-radiation from a ${ }^{63} \mathrm{Ni}$ source. The formation of positive ions is dominated by the proton-transfer reaction (Sunner et al., 1988) from water clusters to substances that have proton affinity higher than water $\left(697 \mathrm{~kJ} \mathrm{~mol}^{-1}\right)$, which includes $\mathrm{NH}_{3}\left(854 \mathrm{~kJ} \mathrm{~mol}^{-1}\right)$. The charged ions are pulsed through a shutter grid into the drift region, were they are separated by mobility and detected at the end of the drift tube by an electrometer. The instrument is not very specific and the $\mathrm{NH}_{3}$ measurement can suffer from the cross sensitivity of other compounds of similar mobility if they also have a proton affinity greater than water, while the quantification can be compromised by competing ion reactions. More details on the IMS technique are given in Hill et al. (1990) and Bacon et al. (1998). In this field study the commercial ion mobility spectrometer RAID I was used (Bruker Daltonik GmbH, Bremen, Germany). Sampling gas flow was $0.41 \mathrm{~min}^{-1}$ and the sampling line was $2 \mathrm{~m}$ non-heated Teflon tubing. Heating was not applied to avoid contamination from the evaporation of $\mathrm{NH}_{4}^{+}$aerosols, although the response time to the concentration peaks might be improved with a heated sampling line.

\subsubsection{Open-path Fourier Transform Infra-Red (OP-FTIR) spectroscopy}

Fourier Transform Infra-Red (FTIR) spectroscopy can be used to identify and quantify substances by their molecular absorption of infra-red radiation at specific wavelengths. An open-path configuration permits the estimation of pathintegrated average concentrations of a gas species of interest over path lengths of up to $1 \mathrm{~km}$. OP-FTIR has been shown to be a useful tool for the measurement of $\mathrm{NH}_{3}$ from agricultural sources (e.g. Griffith and Galle, 2000). In the present study, a MIDAC M4401 portable FTIR spectrometer with Stirling cooled MCT detector module was used in conjunction with a $50.8 \mathrm{~cm}$ infra-red (IR) source in a bi-static openpath configuration (path length of 102 to $105 \mathrm{~m}$ ). Both the FTIR spectrometer and IR source were aligned at 1.3 to $1.4 \mathrm{~m}$ above ground. The spectrometer was operated at a resolution of $0.5 \mathrm{~cm}^{-1}$ and eight sample scans were co-added for each spectrum.

Measured spectra were analysed for $\mathrm{NH}_{3}$ using the $\mathrm{NH}_{3}$ infra-red absorption features at $968 \mathrm{~cm}^{-1}$ and $932 \mathrm{~cm}^{-1}$ (accounting for interference by $\mathrm{H}_{2} \mathrm{O}$ and $\mathrm{CO}_{2}$ absorption). Concentration retrievals were performed using the MALT software (Griffith, 1996). MALT iteratively computes synthetic spectra (convolved to the spectrometer line shape) from the HITRAN absorption line database (Rothman et al., 1998) until the mean-squared difference between the synthetic and measured spectra is minimised. The resultant concentrations used for the best-fit synthetic spectrum yield the pathintegrated $\mathrm{NH}_{3}$ (as well as $\mathrm{H}_{2} \mathrm{O}$ and $\mathrm{CO}_{2}$ ) mixing ratios (in ppbv) for the measured open-path.

\subsection{Calibration and treatment of aerosol components}

The wet chemistry instruments were calibrated weekly with individual liquid standards and a common liquid standard was run on all analytical systems. The CIMS and c-QCLAS were calibrated regularly with their own gas-phase standards. As noted above, the Nitrolux-100 and CRDS were calibrated by manufacturers and operated within the specified calibration intervals. The WaSul-Flux and IMS were calibrated by the operating groups prior to the campaign by comparison against wet-chemistry reference systems.

An inter-comparison calibration (standard addition to ambient air) from a common $\mathrm{NH}_{3}$ gas cylinder took place during the campaign. The cylinder was a standard of nominally $21 \mathrm{ppmv} \mathrm{NH}_{3}$ in $\mathrm{N}_{2}$ (BOC, UK). During the experiment presented here the actual concentration was determined as $20.2 \pm 1.4$ ppmv by bubbling the gas through acid adsorption solution which was then analysed for $\mathrm{NH}_{4}^{+}$by flow injection analysis, following the procedure described by 
Table 2. Correlation of hourly $\mathrm{NH}_{3}$ concentrations less than $10 \mathrm{ppbv}(z=1.1 \mathrm{~m})$ between each instrument and the $\mathrm{NH}_{3}-$ ens. Also shown are the bias for the entire data range and the data $<10 \mathrm{ppbv}$, as well as the gas and liquid standard biases for all instruments.

\begin{tabular}{|c|c|c|c|c|c|c|c|}
\hline \multirow[b]{2}{*}{ Instrument } & \multicolumn{4}{|c|}{$<10 \mathrm{ppb}$ regression } & \multirow[t]{2}{*}{$\begin{array}{r}\text { Overall } \\
\text { bias [\%] }\end{array}$} & \multirow[t]{2}{*}{$\begin{array}{l}\text { Gas Std. } \\
\text { bias [\%] }\end{array}$} & \multirow[t]{2}{*}{$\begin{array}{l}\text { Liquid Std. } \\
\text { bias [\%] }\end{array}$} \\
\hline & Slope & $\begin{array}{r}\text { Intercept } \\
{[\mathrm{ppbv}]}\end{array}$ & $R^{2}$ & Bias [\%] & & & \\
\hline RBD & 0.89 & -0.33 & 0.85 & -20.1 & +5.65 & +13.37 & +2.62 \\
\hline AMANDA & 1.02 & -0.08 & 0.85 & +0.62 & -0.63 & -24.71 & +0.85 \\
\hline AiRRmonia & 0.83 & -0.02 & 0.90 & -17.7 & +10.9 & -18.3 & -2.96 \\
\hline CIMS & 0.95 & +1.93 & 0.65 & +54.5 & -12.9 & -0.26 & N/A \\
\hline c-QCLAS & 0.72 & +0.71 & 0.81 & -12.8 & -4.02 & -23.2 & N/A \\
\hline DUAL-QCLAS & 0.86 & -0.19 & 0.66 & -20.6 & -32.1 & $0 *$ & N/A \\
\hline WaSul-Flux & 0.81 & -0.15 & 0.85 & -22.0 & +1.27 & - & N/A \\
\hline Nitrolux-100 & 0.42 & +3.42 & 0.52 & +2.51 & +1.69 & - & N/A \\
\hline CRDS & 0.50 & +3.14 & 0.56 & +26.0 & +5.10 & -12.48 & N/A \\
\hline IMS & 1.15 & -0.61 & 0.87 & -2.63 & -2.90 & - & N/A \\
\hline
\end{tabular}

* After calibration using this gas standard.

Thomas et al. (2009). The concentration range and number of step increases varied between instruments. A similar calibration scheme is described in Schwab et al. (2007). For each instrument a calibration bias from a $\mathrm{NH}_{3}$ gas cylinder and a corresponding measured $\mathrm{NH}_{3}$ concentration (gas std. bias) was calculated (see Table 2). This gas-phase measurement was used only as a check for most instruments, except for the DUAL-QCLAS, for which it provided the primary calibration, yielding a calibration factor of 1.23.

As outlined in the instrument descriptions above, the wet chemistry systems strip the gas phase from the sample stream, while the aerosol phase passes through the sampling system. The c-QCLAS uses a virtual impactor to prevent most of the particles from entering the detection cell. The Nitrolux-100, CRDS and WaSul-Flux employ filters to prevent aerosol components from contaminating the detection cell. This has the potential to lead to artifacts due to aerosol dynamics on the filter. Indeed, the Nitrolux-100 was initially operated with a used filter and reported elevated $\mathrm{NH}_{3}$ concentration levels compared with the other instruments (the deviation correlating with temperature), suggesting that the $\mathrm{NH}_{3}$ originated from $\mathrm{NH}_{4} \mathrm{NO}_{3}$ volatilisation from the filter. Following replacement of this filter, the Nitrolux-100 measurements were found to agree with the other techniques sharing the same inlet line. The early data were therefore excluded from the data analysis. It appears that, for ambient measurements, the filters provided by the manufacturer have a much shorter lifetime than stated by the manufacturer. The stated lifetime is possibly more appropriate for the clean room applications for which the instrument had originally been developed.

\section{Results}

\subsection{Time-series analysis}

Figure $3 a$ and $b$ show the time-series of measured $\mathrm{NH}_{3}$ during the inter-comparison period of all instruments, measured at different temporal resolutions ( $1 \mathrm{~min}$ to $1 \mathrm{~h}$ ). Different vertical scales were used to present the time-series before (Fig. 3a) and after (Fig. 3b) the fertilisation on $28 \mathrm{Au}$ gust 2008. The $\mathrm{NH}_{3}$ traces from the instruments at their individual time resolution (Table 1) are presented in two groups for increased clarity, separating wet chemistry analysers and spectroscopic techniques. In addition, the wind direction is indicated at the top of Fig. 3a and b. Before the fertilisation (Fig. 3a), there were brief $\mathrm{NH}_{3}$ peaks in the time-series of the DUAL-QCLAS and CIMS of up to 18 ppbv. Except for these individual events, the $\mathrm{NH}_{3}$ level measured by all instruments ranged up to $10 \mathrm{ppbv}$ before the fertilisation event on $28 \mathrm{Au}$ gust 2008. After fertilisation (Fig. 3b), $\mathrm{NH}_{3}$ concentrations increased up to $120 \mathrm{ppbv}$, with such high concentrations continuing until 29 August 2008 around 14:00. The early $\mathrm{NH}_{3}$ peaks and some periods of disagreement coincided with periods when the wind came from the rotting vegetation source in the $\mathrm{N}$ field as indicated by the shaded areas in Fig. $3 \mathrm{a}$ and $\mathrm{b}$.

Overall, the absolute $\mathrm{NH}_{3}$ concentrations of all instruments revealed the same features and agreed closely with each other. By contrast, the different time resolution of the instruments resulted in slightly different features of the temporal $\mathrm{NH}_{3}$ structure. Of the wet chemistry instruments, the 1 minute data of the AiRRmonia analyser shows additional $\mathrm{NH}_{3}$ variations during the fertilisation peak (29 August 2008), which the AMANDA and RBD failed to capture because of their lower time resolution. Similar differences can be seen in the comparison of the spectrometric techniques. 


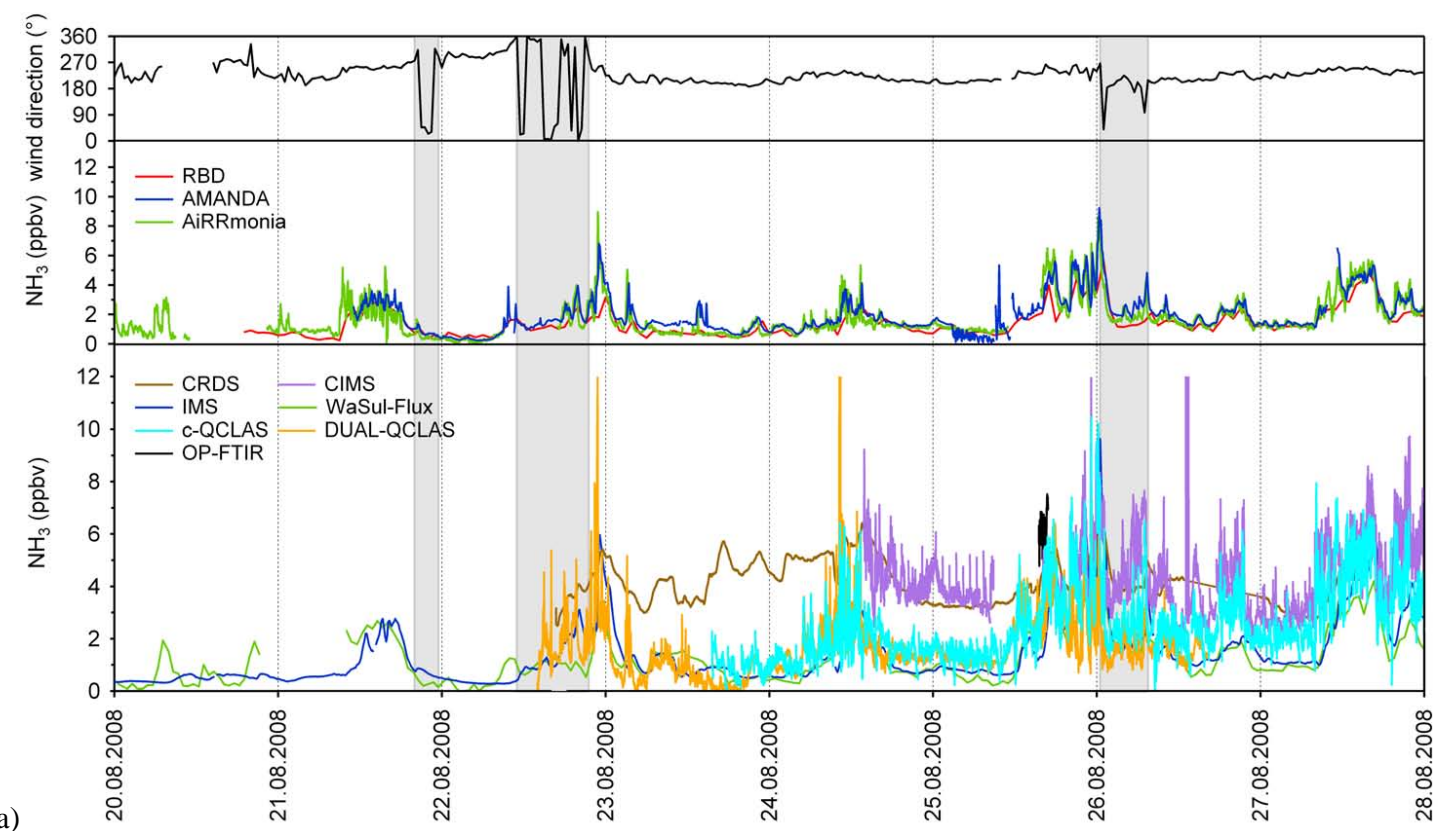

(a)

(b)

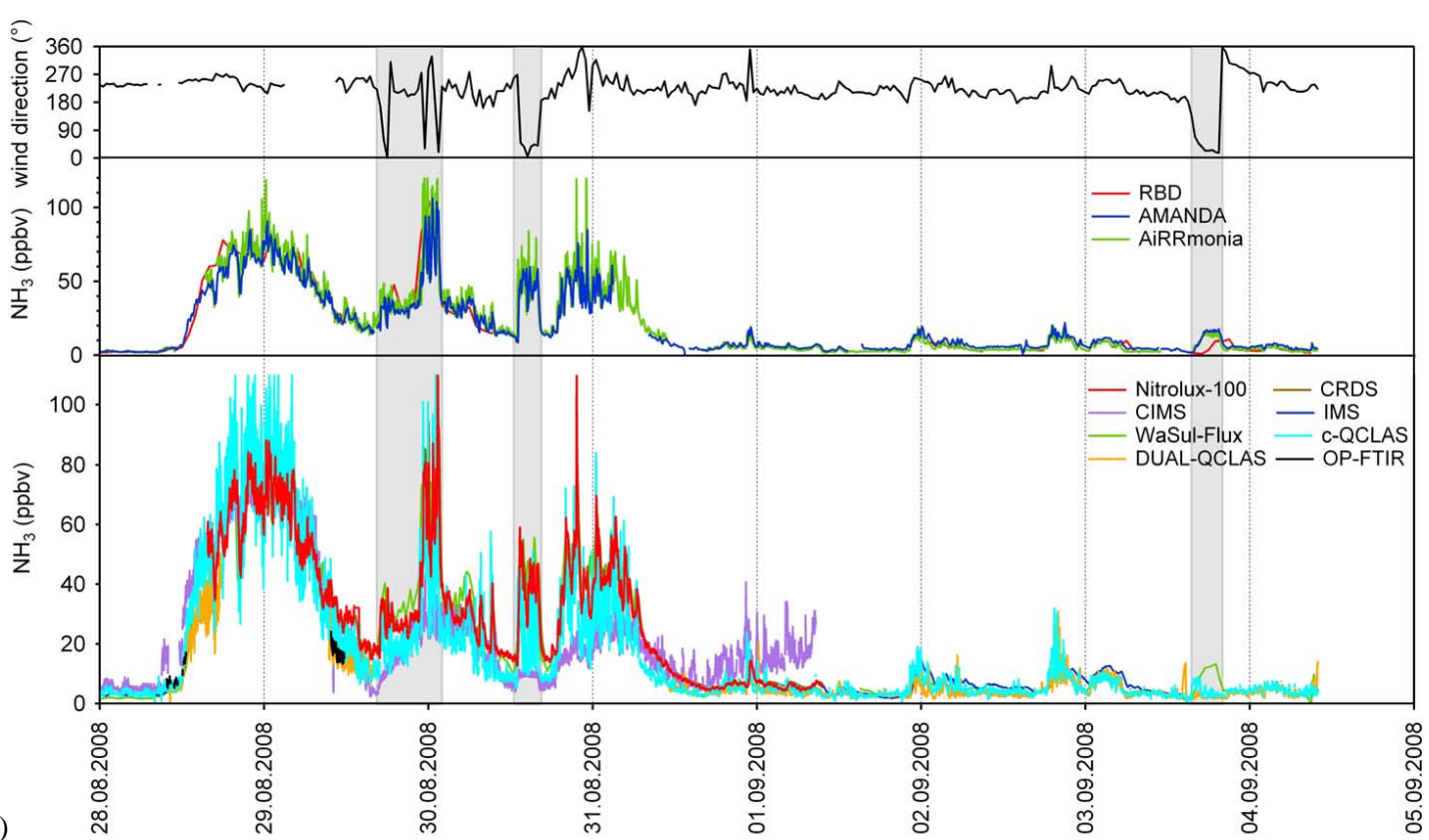

Fig. 3. Times series of $\mathrm{NH}_{3}$ for all instruments $(z=1.1 \mathrm{~m})$ with occurring wind direction for the data (a) before fertilisation and (b) after fertilisation on 28 August 2008. The shaded areas indicate periods during which the wind came from the N field. RBD (red), AMANDA (blue), AiRRmonia (green), Nitrolux-100 (red), CRDS (brown), CIMS (purple), IMS (blue), WaSul-Flux (green), c-QCLAS (cyan), DUALQCLAS (orange), OP-FTIR (black).

\subsection{Instrument inter-comparison}

For the regression analysis data from each instrument was block-averaged to hourly values in order to match the time resolution of the slowest instrument $(\mathrm{RBD})$. In addition, wind directions from the sectors $0^{\circ}$ to $150^{\circ}$ and $310^{\circ}$ to $360^{\circ}$ were excluded from the analysis, due to the heterogeneous source from the rotting vegetation in the $\mathrm{N}$ field.
Figure $4 \mathrm{a}-\mathrm{j}$ depict $\mathrm{NH}_{3}$ concentrations from each instrument compared with the ensemble average of made $\mathrm{NH}_{3} \mathrm{ob}-$ servations $\left(\mathrm{NH}_{3}\right.$-ens $)$, together with the results of the linear regression analysis. The $\mathrm{NH}_{3}$-ens was computed as the average over all instruments that were operational at a given time, excluding the OP-FTIR, for which too few data points were available. Additionally, the horizontal error bars on $\mathrm{NH}_{3}$-ens 

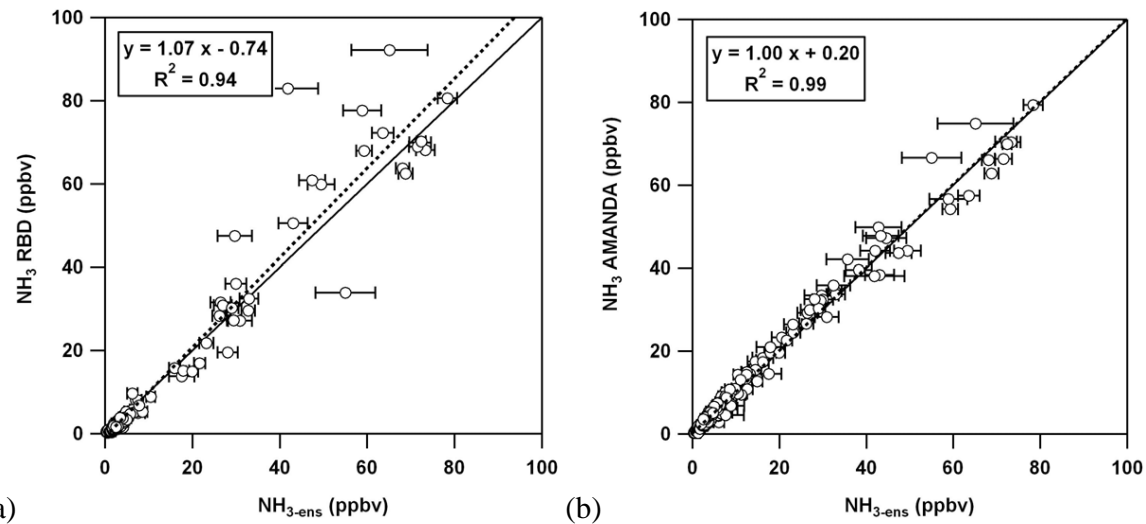

(a)

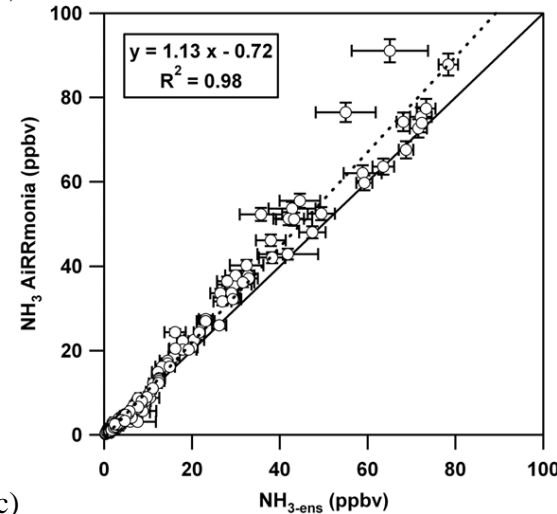

(b)

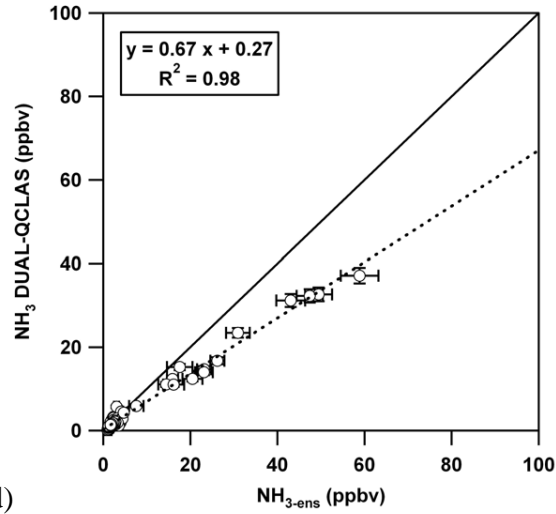

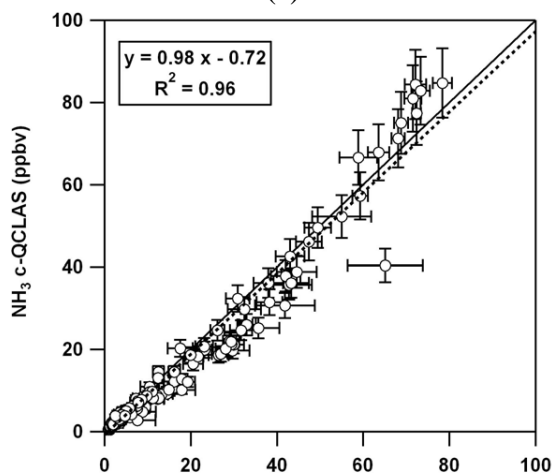

(e)

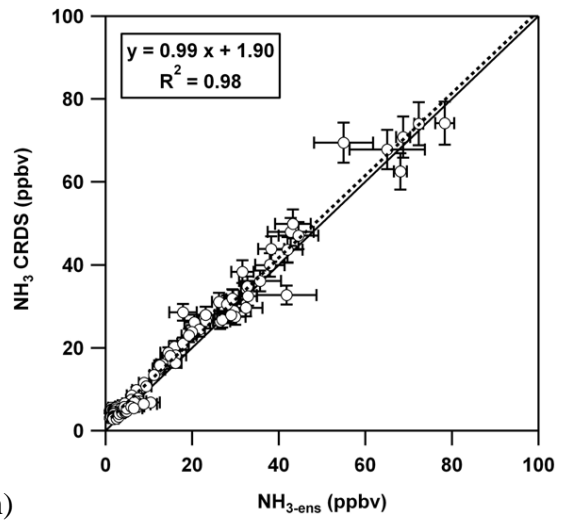

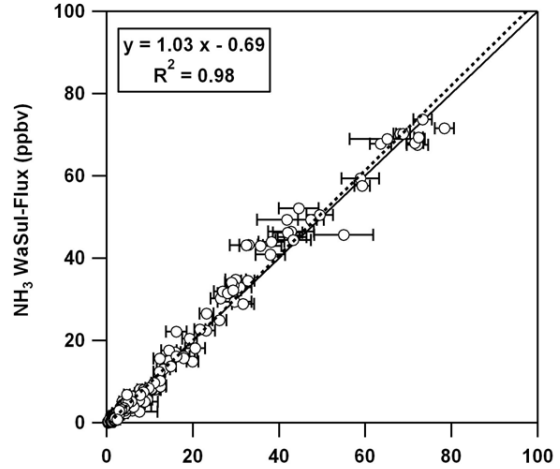

(f)

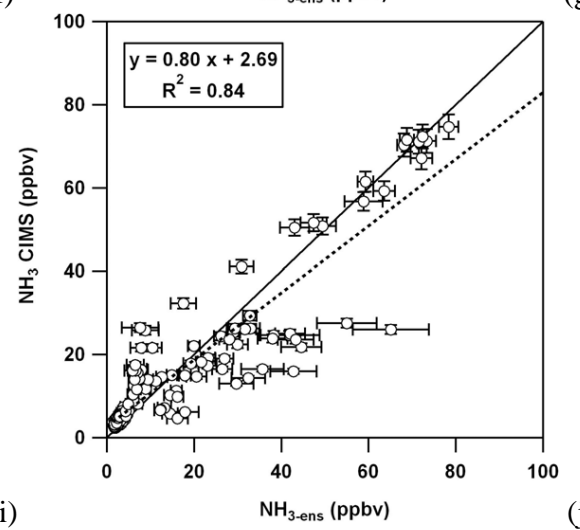

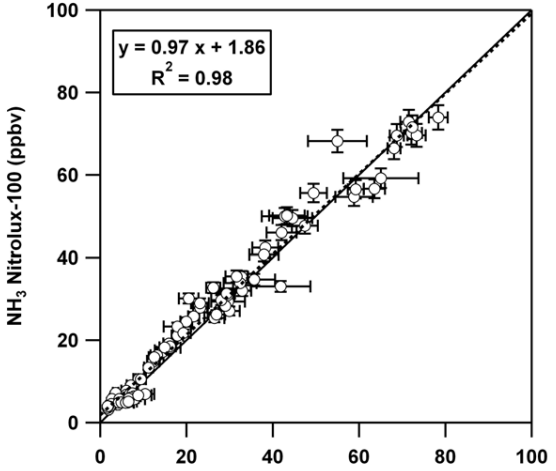

(g)

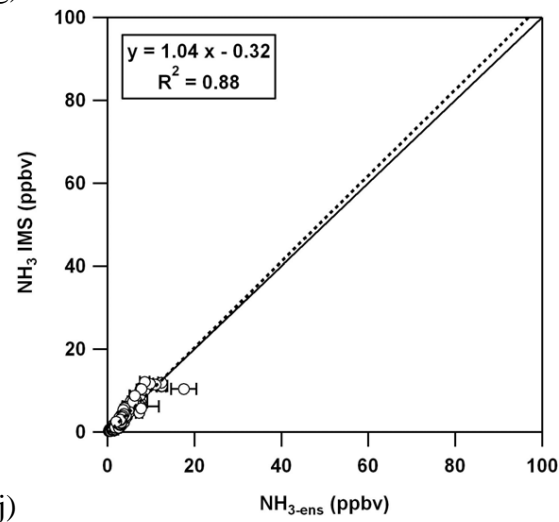

Fig. 4. Scatter plots showing correlation of hourly $\mathrm{NH}_{3}$ concentrations $(z=1.1 \mathrm{~m})$ between all instruments and the $\mathrm{NH}_{3}-$ ens $\mathrm{screened}$ for wind direction $\left(150-310^{\circ}\right)$. The horizontal error bars calculate the statistical standard error. For AiRRmonia, DUAL-QCLAS, c-QCLAS, Nitrolux-100, CRDS and CIMS the vertical error bars mark the estimated accuracy (Table 1). The solid line gives the 1:1 line and the dashed line the result of the axis regression. 
show the statistical standard error (SE) of the different readings from the instruments that went into the calculation of each value of $\mathrm{NH}_{3-\text { ens. }}$ Further, the estimated accuracy for the AiRRmonia, DUAL-QCLAS, c-QCLAS, Nitrolux-100, CRDS and CIMS (Table 1) is shown as vertical error bars.

Overall, a high correlation between all instruments is observed, with $R^{2}>0.84$. The DUAL-QCLAS, c-QCLAS, Nitrolux-100, CRDS and CIMS comparisons with $\mathrm{NH}_{3-\text { ens }}$ have a slope $<1$ (Fig. 4d, e, g, h, i), with the DUAL-QCLAS and the CIMS lowest at 0.67 and 0.80 , respectively. The RBD, AiRRmonia, WaSul-Flux and IMS comparisons with the $\mathrm{NH}_{3}$-ens have a slope $>1$, but have negative intercepts of $-0.74 \mathrm{ppbv}$ (RBD) to $-0.32 \mathrm{ppbv}$ (IMS) (Fig. $4 \mathrm{a}, \mathrm{c}, \mathrm{f}, \mathrm{j}$ ). The AMANDA instrument was closest to $\mathrm{NH}_{3-\text { ens }}$, with a slope of 1 and an intercept of $0.20 \mathrm{ppbv}$ (Fig. 4b). Relatively high intercepts were observed by the CIMS, CRDS and Nitrolux100 compared with the other instruments. It is thought that the CRDS and Nitrolux-100 intercept might be due to a local contamination source which was either on the sampling post, sample tubing (both came from the same batch of tubing) or most likely the inlet filters. It should be noted that for the IMS, only data from before fertilisation and after the fertilisation plume had diminished could be used, because above about $30 \mathrm{ppbv}$ the IMS becomes strongly non-linear due to the consumption of the parent ions and the formation of clusters, which shifts the mobility. The consequence was a reduced dataset, biased towards smaller concentrations.

Accurate measurement of $\mathrm{NH}_{3}$ at typical ambient background levels is more challenging. For this reason, the linear regression for periods when $\mathrm{NH}_{3-\text { ens }}<10 \mathrm{ppbv}$ was calculated separately (Table 2). The $R^{2}$ against $\mathrm{NH}_{3-\text { ens }}$ varied from 0.52 (Nitrolux-100) to 0.90 (AiRRmonia). The slope of AMANDA and IMS against $\mathrm{NH}_{3}$-ens were $>1$ and all others were $<1$, e.g. 0.42 (Nitrolux-100) to 0.95 (CIMS) with intercepts from -0.61 to $3.42 \mathrm{ppbv}$. The highest intercept values were measured for CIMS, CRDS and Nitrolux-100 and again for the latter two inlet/filter contamination are thought to be the cause.

The bias (\%) between two instruments is defined according to Eq. 1, where $m$ is the slope of the regression analysis when forced through zero.

bias $=(m-1) * 100$

The biases reported in Table 2 represent the percentage difference of the full range $\mathrm{NH}_{3}$ concentration (overall bias) and the bias derived from concentrations $<10 \mathrm{ppbv}$ ( $10 \mathrm{ppbv}$ bias). The overall bias for all instruments were reasonably small, ranging from $-12.9 \%$ (CIMS) to $10.9 \%$ (AiRRmonia) except for the DUAL-QCLAS, whereas the 10 ppbv biases showed more variability. Also included in Table 2 is the bias of a reading based on a calibration through standard addition from an $\mathrm{NH}_{3}$ calibration cylinder. It turned out not to be easy to provide a common, reliable and portable gasphase calibration standard suitable for the large range of flow rates of the different instruments. Because these are based on
Table 3. Summary of linear regression results of the OP-FTIR against c-QCLAS, DUAL-QCLAS and CIMS at $2 \mathrm{~min}$ time resolution from the data shown in Fig. 5.

\begin{tabular}{lccc}
\hline & Slope & Intercept (ppbv) & $R^{2}$ \\
\hline c-QCLAS & 0.54 & 4.39 & 0.97 \\
DUAL-QCLAS & 0.82 & 3.74 & 0.92 \\
CIMS & 0.43 & 5.37 & 0.63 \\
\hline
\end{tabular}

standard additions to ambient air, they only reflect the error on the response (slope) and do not include the intercept. Calibration results were more variable than the slopes derived from the regression analysis and should therefore be treated with caution.

For the wet-chemistry analysers a liquid intercalibration was performed using common 50, 100 and 500 ppbv aqueous standard on the three analytical systems and the outcome is again the regression with the measured percentage difference. For the three wet-chemistry instruments the used liquid standards showed excellent agreement concerning the liquid standard bias (Table 2).

The OP-FTIR was operated manually in the field and the dataset is much reduced compared with the other instruments $(9 \mathrm{~h})$. Thus, it is not included in the hourly data analysis. Instead, Fig. 5 compares the OP-FTIR data at 2 min time resolution against the other fast response instruments (c-QCLAS, DUAL-QCLAS and CIMS).

The data of the OP-FTIR agreed best with the DUALQCLAS (Fig. 5) with a slope of 0.82 (Table 3), which was reading lower compared to the other instruments (Fig. 4d) with the c-QCLAS providing the best match with the reference here. Further, the regression analysis revealed for the OP-FTIR a high intercept of $>3.74 \mathrm{ppbv}$ compared with all other instruments.

While for graphical representation the analysis of an individual instrument against a common $\mathrm{NH}_{3}$-ens provides a digestible overview over the results, the full information of the inter-comparison is only revealed through correlation between each of the eleven instruments with each other. Tables 4 and 5 show the results of the regression analysis of all hourly data, while Tables 6 and 7 show the results of the regression confined to data points where both instruments reported concentrations of less than 10 ppbv. Each of the four tables contains two separate diagonal parts with information for the instruments. For the top half of the table (grey) the regression provided is the vertical axis (row) against the horizontal axis (column). Concerning the bottom half it switches to horizontal axis (column) against vertical axis (row).

For example, the regression analysis of the RBD against the AMANDA for the entire data range is:

$$
\begin{aligned}
\mathrm{RBD} & =0.86 * \mathrm{AMANDA}+1.41 \mathrm{ppbv}, \\
R^{2} & =0.93 \\
\text { bias } & =-11.1 \%
\end{aligned}
$$




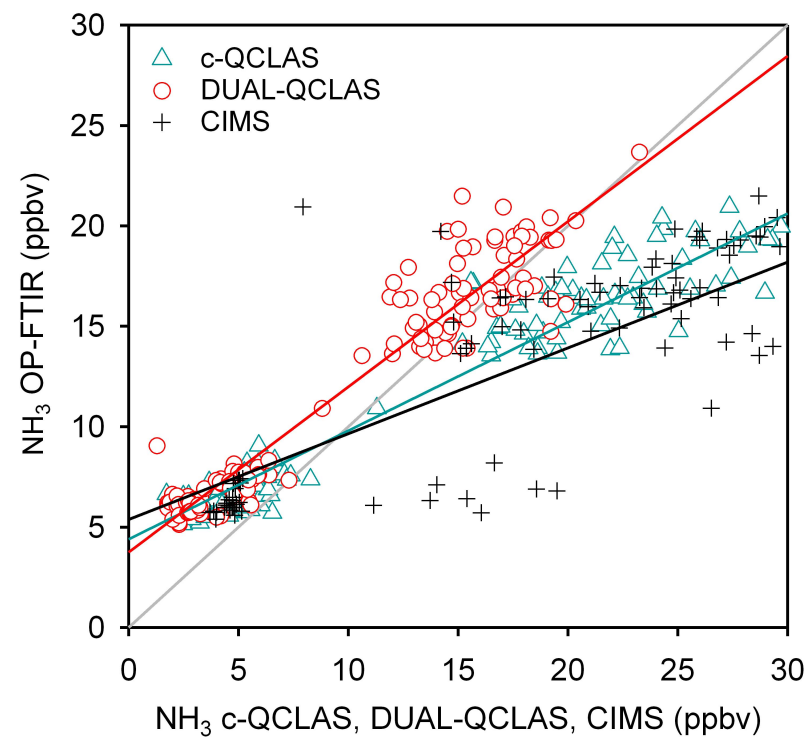

Fig. 5. Scatter plots of OP-FTIR against c-QCLAS, DUAL-QCLAS and CIMS at 2 min time resolution, including regression lines and the $1: 1$ line (grey).

while the results of the regression analysis of the AMANDA vs. RBD are not included. Although derived from the regression fit of $y=a x$, the bias does not always fully represent a clear picture of the combined effects of the average discrepancy between two instruments specify by slope and intercept. For example, due to a lack of data and high intercept values for some instruments, the datasets in these scatter plots showed a distributed appearance and the linear regression line was difficult to draw (Table 8). Thus all four parameters need to be considered when interpreting the performance of two instruments against each other.

For the overall data range the slopes of the AMANDA, AiRRmonia, c-QCLAS, WaSul-Flux, Nitrolux-100 and CRDS varied by $\pm 20 \%$ with each other (Table 4 ). For the data limited to $<10$ ppbv the slopes between RBD, AiRRmonia, WaSul-Flux and IMS were all within $\pm 20 \%$ of unity (Table 6). High intercepts were found for correlations of CIMS, Nitrolux-100 and CRDS with all other instruments (Bold numbers in Tables 4 and 6), with values from 1.60 to $6.14 \mathrm{ppbv}$ for the full data range and from 1.22 to $3.92 \mathrm{ppbv}$ for data $<10$ ppbv. For the full data range, $R^{2}$ values $<0.90$ were limited for inter-comparisons involving RBD, CIMS or IMS (Table 5). For $<10 \mathrm{ppbv}$, an $R^{2}>0.80$ was achieved for any comparison between AMANDA, AiRRmonia and cQCLAS (Table 7). The DUAL-QCLAS (italic numbers in Tables 5 and 7) was biased towards lower values, compared with all other instruments.

Table 8 contains two separate diagonal parts with information and presents a visual support to the results from Tables 4 to 7 . The results provided are for the regression of the instrument on the vertical axis (row) against the instrument on the horizontal axis (column) for the entire data range (white).

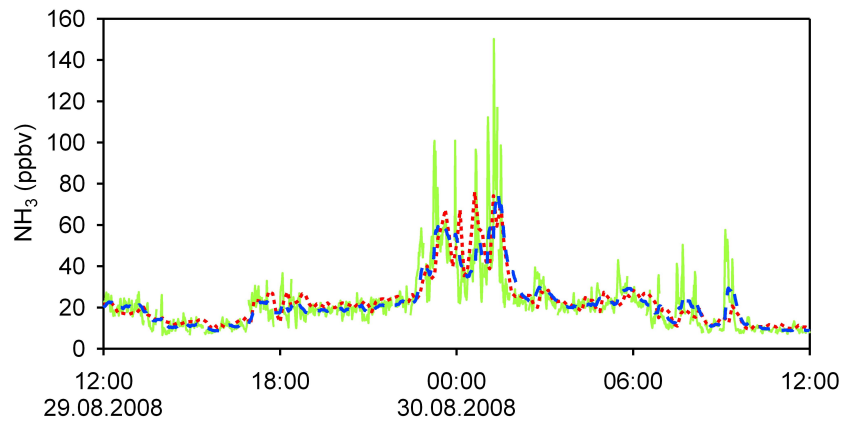

Fig. 6. Comparison of the time-series of the AMANDA (red/dotted) and the c-QCLAS (green) for a $24 \mathrm{~h}$ period on 29 to 30 August 2008. The c-QCLAS smoothed concentration $c^{\prime}(t)$ (blue/dashed) was calculated with $f=0.08$, selected by eye as a fit to the AMANDA data.

The grey diagonal part shows the plots for $\mathrm{NH}_{3}$ concentration $<10 \mathrm{ppbv}$ and it is to read from the instruments in the horizontal axis (row) against instruments in the vertical axis (column). For more visibility and detailed information see the supplemental material (http://www.atmos-meas-tech.net/ 3/91/2010/amt-3-91-2010-supplement.pdf).

\subsection{Characterisation of the instrument time responses of the slow response instruments}

For analysing the time response of the different instrument setups (including inlets) a short time-series of each instrument was compared against data of a well-performing fastresponse instrument, for which the $1 \mathrm{~min}$ data from the cQCLAS was chosen. A running mean was calculated from the c-QCLAS data as:

$c^{\prime}(t)=f c(t)+(1-f) c^{\prime}(t-1)$

where $c^{\prime}(t)$ is the smoothed concentration, $c(t)$ is the measured concentration and $f$ is a smoothing factor defined below, which would be unity for an instrument that is equally as fast as the c-QCLAS. Equation (2) simulates the response of a concentration measurement which is subject to a memory effect, which may be either due to the turnover time in an air volume, liquid pool or due to adsorption/desorption in inlet lines. For each instrument $f$ was determined by fitting the smoothed c-QCLAS time-series to the data reported by the instrument. This approach is demonstrated in Fig. 6, where $f$ is adjusted for the smoothed c-QCLAS time-series to match the data from the AMANDA.

The e-folding time of the instrument was determined as $\tau_{1 / e}=1 / f$ min, which is reported in Table 9 together with the 50 and $95 \%$ response times $\left(\tau_{50}, \tau_{95}\right)$. The corresponding deviation is also stated.

The AMANDA reports $7.5 \mathrm{~min}$ data, but it appeared to take $32.2 \pm 3.7 \mathrm{~min}$ for a $95 \%$ response. The replacement of the liquid pool in the denuder appears to limit this time response of the instrument. A similar observation was made 
Table 4. Inter-comparison of linear correlations between each instrument for the entire data range. Slopes are given in the bottom half and intercepts are indicated by the top (grey) of the matrix. Bold numbers indicate noticeable non-zero intercepts ( $>1.5 \mathrm{ppbv})$.

\begin{tabular}{|c|c|c|c|c|c|c|c|c|c|c|c|}
\hline & & $\stackrel{0}{\simeq}$ & 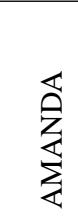 & $\begin{array}{l}\cdot \frac{\pi}{\exists} \\
\stackrel{0}{\Xi} \\
\frac{a}{a} \\
\frac{a}{4}\end{array}$ & $\sum_{U}^{\infty}$ & 岕 & 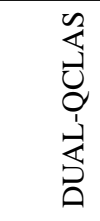 & 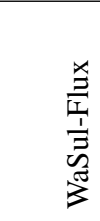 & $\begin{array}{l}\stackrel{凶}{ٍ} \\
\text { 를 }\end{array}$ & مิ & $\sum_{\Sigma}^{\mathscr{N}}$ \\
\hline \multicolumn{12}{|c|}{ Intercept [ppbv] } \\
\hline RBD & \multirow{10}{*}{$\frac{\ddot{\alpha}}{\sqrt{n}}$} & - & 1.41 & 0.70 & 3.65 & 1.17 & 1.09 & 0.55 & 6.14 & 3.63 & 0.10 \\
\hline AMANDA & & 0.86 & - & -1.08 & 3.51 & -0.62 & 0.34 & -0.86 & 1.82 & 2.27 & 0.04 \\
\hline AiRRmonia & & 0.97 & 1.12 & - & 3.92 & 0.34 & 0.57 & 0.16 & 2.65 & 2.93 & 0.02 \\
\hline CIMS & & 0.74 & 0.76 & 0.65 & - & -2.46 & -0.38 & -1.07 & 4.12 & 1.60 & 0.78 \\
\hline c-QCLAS & & 0.86 & 0.96 & 0.83 & 1.09 & - & 0.64 & 0.47 & 5.73 & 3.25 & 0.10 \\
\hline DUAL-QCLAS & & 0.54 & 0.69 & 0.59 & 0.64 & 0.65 & - & -1.13 & 2.46 & 1.81 & 0.40 \\
\hline WaSul-Flux & & 0.90 & 1.02 & 0.90 & 1.06 & 1.00 & 1.55 & - & 3.09 & 3.02 & 0.19 \\
\hline Nitrolux-100 & & 0.77 & 0.96 & 0.85 & 0.97 & 0.90 & 1.53 & 0.92 & - & -0.03 & -2.22 \\
\hline CRDS & & 0.81 & 0.93 & 0.83 & 1.09 & 1.04 & 1.60 & 0.92 & 1.00 & - & -1.13 \\
\hline IMS & & 1.12 & 0.88 & 1.11 & 0.30 & 0.93 & 0.69 & 1.11 & 0.95 & 0.65 & - \\
\hline
\end{tabular}

Table 5. Inter-comparison of correlation coefficients and biases between each instrument for the entire data range. Biases are given in the bottom half and correlation coefficients are indicated by the top (grey) of the matrix. Bold numbers indicate high biases ( $>20 \%$ ), mainly of the Dual-QCLAS.

\begin{tabular}{|c|c|c|c|c|c|c|c|c|c|c|c|}
\hline & & 全 & 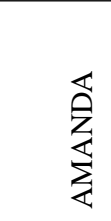 & 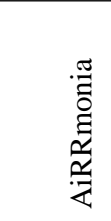 & $\sum_{0}^{\infty}$ & 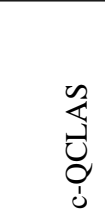 & 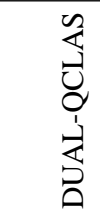 & 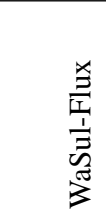 & 若 & $\tilde{\theta}$ & $\sum^{\infty}$ \\
\hline \multicolumn{12}{|c|}{$R^{2}$} \\
\hline RBD & \multirow{10}{*}{$\frac{\sqrt[a]{a}}{\frac{\pi}{0}}$} & - & 0.93 & 0.93 & 0.82 & 0.87 & 0.95 & 0.95 & 0.84 & 0.86 & 0.80 \\
\hline AMANDA & & -11.1 & - & 0.99 & 0.76 & 0.92 & 0.97 & 0.98 & 0.98 & 0.98 & 0.90 \\
\hline AiRRmonia & & -1.77 & 9.41 & - & 0.74 & 0.91 & 0.98 & 0.98 & 0.96 & 0.97 & 0.82 \\
\hline CIMS & & -18.8 & -15.6 & -26.8 & - & 0.89 & 0.94 & 0.79 & 0.75 & 0.71 & 0.58 \\
\hline c-QCLAS & & -11.7 & -5.91 & -15.8 & 1.96 & - & 0.97 & 0.93 & 0.93 & 0.93 & 0.70 \\
\hline DUAL-QCLAS & & -43.4 & -29.8 & -38.9 & -37.7 & $-\mathbf{3 3 . 0}$ & - & 0.98 & 0.97 & 0.91 & 0.66 \\
\hline WaSul-Flux & & -8.85 & -0.3 & -9.50 & 3.19 & 1.80 & 48.3 & - & 0.95 & 0.95 & 0.82 \\
\hline Nitrolux-100 & & -12.4 & 0.33 & -9.83 & 8.00 & 2.62 & 65.0 & -1.40 & - & 0.99 & 0.57 \\
\hline CRDS & & -10.7 & -0.2 & -10.6 & 14.7 & 13.8 & 86.4 & -0.12 & 0.37 & - & 0.20 \\
\hline IMS & & 14.3 & -10.9 & 10.9 & -60.8 & -5.58 & -19.9 & 15.2 & -51.1 & -60.5 & - \\
\hline
\end{tabular}

for the RBD. The AiRRmonia seemed to have the least time delays in the system: $\tau_{95}$ of $14.4 \pm 4.0$ min closely matched the internal measurement cycle of $10 \mathrm{~min}$.

The IMS derived with $\tau_{95}=34.9 \pm 6.4$ min the highest delay with reported data of $3 \mathrm{~s}$, but the limited amount of data qualified this statement. The CIMS and DUAL-QCLAS have similar time responses as the c-QCLAS and this approach is therefore not suitable to characterise them further. They are therefore not listed in Table 9.

\section{Discussion}

\subsection{Overall measurement agreement}

The instruments tested in the present study revealed good correlation with $R^{2}>0.84$ for one hour averages compared

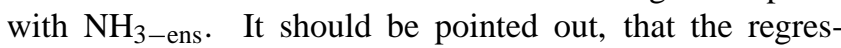
sions show relative performance of the instruments against $\mathrm{NH}_{3 \text {-ens }}$ (Fig. 4a-j) or against each other (Tables 4, 6, 8). They do not demonstrate a functional relationship of a dependent to an independent variable. Thus, a consideration 
Table 6. Inter-comparison of linear correlations between each instrument of data less than $10 \mathrm{ppbv}$. Slopes are given in the bottom half and intercepts are indicated by the top (grey) of the matrix. Bold numbers indicate noticeable non-zero intercepts $(>1.5 \mathrm{ppbv})$.

\begin{tabular}{|c|c|c|c|c|c|c|c|c|c|c|c|}
\hline & & $\stackrel{0}{\underline{a}}$ & 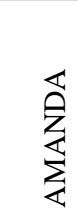 & 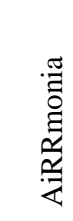 & $\sum_{U}^{\infty}$ & 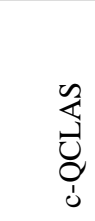 & 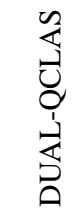 & 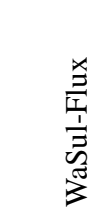 & 峞 & $\tilde{\vartheta}$ & $\sum^{\infty}$ \\
\hline \multicolumn{12}{|c|}{ Intercept [ppbv] } \\
\hline RBD & \multirow{10}{*}{$\frac{\ddot{O}}{\sim}$} & - & 0.37 & 0.48 & 3.08 & 1.22 & 0.48 & 0.28 & 3.92 & 3.82 & 0.02 \\
\hline AMANDA & & 1.15 & - & 0.20 & 2.95 & 1.02 & 0.34 & -0.06 & 3.75 & 3.42 & -0.09 \\
\hline AiRRmonia & & 0.85 & 0.73 & - & 2.64 & 0.84 & 0.05 & 0.01 & 3.26 & 3.58 & -0.14 \\
\hline CIMS & & 0.71 & 0.68 & 0.89 & - & -0.62 & 0.28 & -0.81 & 2.51 & 1.22 & -0.88 \\
\hline c-QCLAS & & 0.79 & 0.64 & 0.86 & 0.81 & - & 0.16 & -0.68 & 3.47 & 3.46 & -0.64 \\
\hline DUAL-QCLAS & & 0.86 & 0.70 & 1.03 & 0.35 & 0.78 & - & 0.09 & 3.90 & 3.91 & 0.30 \\
\hline WaSul-Flux & & 0.85 & 0.77 & 0.94 & 0.56 & 1.03 & 0.79 & - & 3.47 & 3.75 & 0.10 \\
\hline Nitrolux-100 & & 0.40 & 0.40 & 0.51 & 0.52 & 0.53 & 0.43 & 0.52 & - & -0.05 & -2.22 \\
\hline CRDS & & 0.25 & 0.46 & 0.44 & 0.69 & 0.46 & 0.24 & 0.58 & 1.02 & - & -1.13 \\
\hline IMS & & 1.14 & 0.93 & 1.17 & 0.68 & 1.15 & 0.75 & 1.13 & 0.95 & 0.65 & - \\
\hline
\end{tabular}

Table 7. Inter-comparison of correlation coefficients and biases between each instrument of data less than 10 ppbv. Biases are given in the bottom half and correlation coefficients are indicated by the top (grey) of the matrix. Bold numbers indicate high biases ( $>20 \%$ ).

\begin{tabular}{|c|c|c|c|c|c|c|c|c|c|c|c|}
\hline & & $\stackrel{\vartheta}{\underline{\imath}}$ & 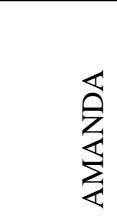 & 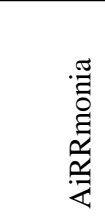 & $\sum_{\circlearrowright}^{\infty}$ & 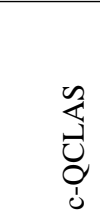 & 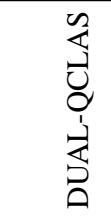 & 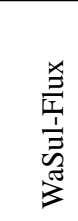 & $\stackrel{\stackrel{㐅}{\Xi}}{\stackrel{\Xi}{\Xi}}$ & مิ & $\sum_{\Sigma}^{\mathscr{Z}}$ \\
\hline \multicolumn{12}{|c|}{$R^{2}$} \\
\hline RBD & \multirow{10}{*}{$\frac{\sqrt{a}}{\frac{a}{n}}$} & - & 0.81 & 0.79 & 0.37 & 0.72 & 0.51 & 0.77 & 0.21 & 0.09 & 0.79 \\
\hline AMANDA & & 26.8 & - & 0.91 & 0.40 & 0.81 & 0.52 & 0.90 & 0.45 & 0.46 & 0.83 \\
\hline AiRRmonia & & -0.46 & -22.7 & - & 0.55 & 0.91 & 0.62 & 0.85 & 0.79 & 0.43 & 0.73 \\
\hline CIMS & & 105 & 66.7 & 91.6 & - & 0.43 & 0.20 & 0.54 & 0.44 & 0.55 & 0.40 \\
\hline c-QCLAS & & 12.6 & -14.9 & 6.66 & -31.6 & - & 0.63 & 0.82 & 0.33 & 0.27 & 0.66 \\
\hline DUAL-QCLAS & & 10.5 & -16.8 & 5.40 & $-\mathbf{5 8 . 5}$ & -16.2 & - & 0.62 & 0.06 & 0.11 & 0.46 \\
\hline WaSul-Flux & & -6.87 & -23.7 & -5.45 & -59.9 & -12.3 & -17.5 & - & 0.62 & 0.50 & 0.78 \\
\hline Nitrolux-100 & & 101 & 12.3 & 16.6 & -1.96 & 35.7 & 146 & 41.8 & - & 0.72 & 0.57 \\
\hline CRDS & & 107 & 32.8 & 46.0 & -6.32 & 45.5 & 96.3 & 68.4 & 1.21 & - & 0.20 \\
\hline IMS & & 14.8 & -49.45 & 12.5 & -50.7 & -2.33 & -12.2 & 16.0 & -51.1 & -60.5 & - \\
\hline
\end{tabular}

of an a priori uncertainty would not be appropriate for this analysis. Nevertheless, a possible approach of performing regression analysis by using a least-squares fitting with uncertainties of the data can be found in Cantrell (2008).

The CIMS, CRDS and Nitrolux-100 revealed elevated intercepts compared with the other instruments pointing at a possible contamination of the inlet filters (CRDS and Nitrolux-100), inlets or both. The detected results during this campaign are in line with the studies listed below. Measurements of RBD, AMANDA, AiRRmonia, WaSulFlux and c-QCLAS were within $\pm 25 \%$ for $\mathrm{NH}_{3}$ concentrations of 10 to $120 \mathrm{ppbv}$.
It should be noted that, although an attempt was made to eliminate the effect of spatial heterogeneity, emissions from grazed and fertilised grassland are expected to show some variability. It was neither possible (though desirable) for all instrument to sample from a common point (e.g. the wet chemistry instruments do not use an inlet tube, while the OP-FTIR provides a line average), nor was the use of a common inlet in the spirit of this experiment, in which we wanted to test independent systems with the respective inlets as they would have been operated by the different groups in the field. There is some indication that at times, instruments that were located more closely to 
Table 8. Linear regression between each instrument for the entire data range (bottom left) and less than 10 ppbv (shaded top right).

\begin{tabular}{|c|c|c|c|c|c|c|c|c|c|c|}
\hline & $\underline{\theta}$ & $\underset{\sum}{\mathbb{Z}}$ & $\begin{array}{l}\cdot \frac{\sigma}{\Xi} \\
\frac{\sigma}{\Xi} \\
\frac{\alpha}{\alpha} \\
\frac{\alpha}{z}\end{array}$ & $\sum_{\circlearrowright}^{\infty}$ & 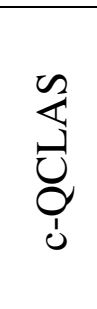 & 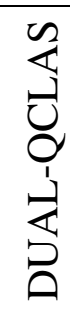 & $\begin{array}{l}\frac{x}{J} \\
\frac{1}{I} \\
\bar{J} \\
\tilde{J} \\
3\end{array}$ & 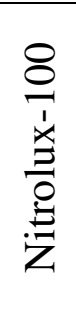 & $\stackrel{\mathscr{\theta}}{\tilde{u}}$ & $\sum_{i}^{\infty}$ \\
\hline RBD & _- & & & & & & & & & \\
\hline AMAND & & & & & & & & & & \\
\hline AiRRmo & & & & & & & & & & \\
\hline CIMS & & & & & & & & & & \\
\hline c-QCLA & & & & & & & & & & \\
\hline DUAL-QC & & & & & & & & & & \\
\hline WaSul-F & & & & & & & & & & \\
\hline Nitrolux- & & & & & & & & & & \\
\hline CRDS & & & & & & & & & & \\
\hline IMS & & & & & & & & & & \\
\hline
\end{tabular}

each other (e.g. WaSul-Flux/AMANDA/RBD/AiRRmonia and CIMS/DUAL-QCLAS/c-QCLAS/Nitrolux-100/CRDS) agreed more closely with each other, but this observation was not consistent.

Previous comparison campaigns have already illustrated the challenges involved in measuring ambient $\mathrm{NH}_{3}$ concentrations accurately, especially at low concentrations. The results in the study of Wiebe et al. (1990) showed an agreement within $\pm 30 \%$ for $\mathrm{NH}_{3}$ concentration $>1.5 \mathrm{ppbv}$ with time resolution of minimum four hours for the filter packs and the annular denuders. The five instruments compared by William et al. (1992) yielded an agreement of within a factor of two for $\mathrm{NH}_{3}$ concentration $>0.5 \mathrm{ppbv}$. In detail the CAD/IC and PF/LIF agreed within $15 \%$ for $\mathrm{NH}_{3}$ concentration of 0.2 to $5.0 \mathrm{ppbv}$ for a time resolution of 2 to $8 \mathrm{~h}$. The framework of the NAQMN study by Mennen et al. (1996) determined a general applicability for all requirements for air quality monitoring on one hour sampling. Further, the DOAS and the $\mathrm{NO}_{\mathrm{x}}$ converter instruments reached $R^{2}>0.9$ compared with the wet-annular rotating denuder, but both were only useful during high $\mathrm{NH}_{3}$ concentration near stacks or stables. In the study by Mennen et al. (1996) 
Table 9. Analysis of the response time of AMANDA, RBD, WaSulFlux, AiRRmonia, Nitrolux-100, CRDS and IMS in comparison to c-QCLAS with corresponding statistical parameters.

\begin{tabular}{lccc}
\hline & $\begin{array}{c}\tau_{1 / e} \\
(\mathrm{~min})\end{array}$ & $\begin{array}{c}\tau_{50} \\
(\mathrm{~min})\end{array}$ & $\begin{array}{c}\tau_{95} \\
(\mathrm{~min})\end{array}$ \\
\hline AMANDA & $10.7 \pm 1.3$ & $7.4 \pm 0.9$ & $32.2 \pm 3.7$ \\
RBD & $28.7 \pm 4.2$ & $19.9 \pm 2.9$ & $85.9 \pm 12.5$ \\
WaSul-Flux & $19.1 \pm 5.4$ & $13.3 \pm 3.7$ & $57.3 \pm 16.1$ \\
AiRRmonia & $4.8 \pm 1.4$ & $3.4 \pm 0.9$ & $14.4 \pm 4.0$ \\
Nitrolux-100 & $3.6 \pm 0.8$ & $2.5 \pm 0.6$ & $10.9 \pm 2.5$ \\
CRDS & $4.5 \pm 1.7$ & $3.1 \pm 1.2$ & $13.4 \pm 5.0$ \\
IMS & $11.6 \pm 2.1$ & $8.1 \pm 1.5$ & $34.9 \pm 6.4$ \\
\hline
\end{tabular}

the photoaccoustic monitor was eliminated due to high maintenance demands and because of leaving only $1 \%$ useful data. During the campaign of Milford et al. (2000) AMANDA and DS-FIA showed an overall difference of $35 \%$ for a sampling time of $30 \mathrm{~min}$, but with substantial scatter. Fehsenfeld et al. (2002) reported for CIMS and $\mathrm{MoO}_{\mathrm{x}}$ converter method $R^{2}>0.9$ compared with the citric acid denuder (sampling time minimum two hours). The average concentration difference compared with the denuder was 0.8 for the CIMS and 1.75 for the $\mathrm{MoO}_{\mathrm{x}}$ converter method. Two CIMS instruments tested during the field study in Nowak et al. (2006) measured $R^{2}=0.71$ and concentration difference of $17 \%$ (time resolution one minute) with $\mathrm{NH}_{3}$ concentrations from 0.4 to 0.13 ppbv. Milford et al. (2009) compared measurements with three AMANDA systems and a mini-WEDD system. The $\mathrm{NH}_{3}$ measurements showed good agreement between the instruments $(<20 \%$ difference) for some periods, but with poorer agreement on some individual days, due to variable performance of the automatic wet chemistry detection systems.

Of particular interest here are the results of the recent laboratory inter-comparison study of Schwab et al. (2007), because it followed a complementary approach (being laboratory based), while including some of the same instrument models tested here. The seven instruments tested during the laboratory comparison agreed within $25 \%$ of the expected calibration value. The IMS and Nitrolux-100 yielded biases of $\pm 25 \%$ with slower time response than the TDLAS (similar to the QCLAS used here). Further, the wet chemical instruments LOPAP and WEDD worked well in the calibration tests in view of absolute accuracy of measured concentrations, but a disadvantage was the slower time response of the WEDD.

In the recent field inter-comparison of Norman et al. (2009) the slopes of hourly uncorrected data of PTRMS (an alternative CIMS technique using a different ionisation scheme), GRAEGOR (based on the same collection and analytical technique as the AMANDA, but with lower flow rates) and AiRRmonia ranged between 0.78 to 0.97 for $\mathrm{NH}_{3}$ concentrations from 2 to $25 \mathrm{ppbv}$. During atmospheric conditions favouring condensation in inlet lines, the PTRMS underestimated $\mathrm{NH}_{3}$ concentrations. The authors point out the need to put more emphasis on the inlet designs for future campaigns. Whitehead et al. (2008) reported that their concentration measurements from the QCLAS and the AMANDA instrument correlated well, with $R^{2}=0.84$. However, the QCLAS underestimated fluxes by $64 \%$ compared with the AMANDA instrument.

\subsection{Instrument specific issues}

While providing a good response to the concentrations, the Nitrolux-100 and CRDS measurements in the present study were subject to a similar high intercept compared with the other instruments. There were two aspects common to these instruments: they shared the same sampling line, which may have been contaminated, but they also both use inlet filters, exchanged infrequently (up to 3 months, according to manufacturers), which may collect $\mathrm{NH}_{4} \mathrm{NO}_{3}$ which then could dissociate at low concentrations, providing a (temperature dependent) offset. This process clearly affected the Nitrolux100 data at the start of the experiment, taken with an old filter, which were discarded from the analysis. This inlet / filter issue may also have affected the regressions of these instruments, especially over the low concentration range, as the intercept may not be stable in time. Apart from this issue, both instruments are convenient to operate as they are both manufacturer calibrated with long service intervals.

The only other instrument using an inlet filter is the WaSul-Flux, which operates on a similar principle as the Nitrolux-100. However, its filter was changed weekly, minimising the effect of $\mathrm{NH}_{4} \mathrm{NO}_{3}$ volatilisation. An attempt was made to investigate the potential of $\mathrm{NH}_{4} \mathrm{NO}_{3}$ interference on those instruments that do not remove the aerosol phase. In the c-QCLAS inlet a virtual impactor removes the coarse aerosol fraction. The CIMS does not use a filter and the residence within the heated inlet is $0.1 \mathrm{~s}$ and thus, the interference from $\mathrm{NH}_{4} \mathrm{NO}_{3}$ volatilisation is expected to be negligible, as noted by Fehsenfeld et al. (2002). Indeed, laboratory tests have shown that $\mathrm{NH}_{4} \mathrm{NO}_{3}$ volatilisation only becomes an issue for $T>325 \mathrm{~K}$. Filters were not used on the IMS and the DUAL-QCLAS systems either, but the residence time in the analysis cell of the DUAL-QCLAS is of the order of $0.2 \mathrm{~s}$ and laboratory tests have found $\mathrm{NH}_{4} \mathrm{NO}_{3}$ interference to be negligible. In the wet chemistry systems aerosols are thought to pass the inlet uncollected. Unfortunately, the regional $\mathrm{NH}_{4}^{+}$concentration was fairly constant during the campaign (Fig. 2), except for a period which coincided with the fertiliser emission peak of $\mathrm{NH}_{3}$, during which $\mathrm{NH}_{4}^{+}$still made a minor contribution to total $\mathrm{NH}_{\mathrm{x}}$. As a consequence, the effect of inlet heating (to $50^{\circ} \mathrm{C}$ ) on $\mathrm{NH}_{4} \mathrm{NO}_{3}$ volatilisation in the WaSul-Flux inlet could not be investigated. 
The WaSul-Flux performed well against the other instruments, but has a relatively slow time response $(45 \mathrm{~min})$ at the background concentrations. It can achieve a detection limit of $0.25 \mathrm{ppbv}$ at $45 \mathrm{~min}$ time resolution (Table 1), which may still not be sufficient for all applications. Work is underway to improve the sensitivity further.

By contrast, the IMS is highly sensitive, but less specific and affected by competing ion chemistries, which makes it applicable only to situations of low $\mathrm{NH}_{3}$ and where no interfering compounds are to be expected. Its comparatively poor performance over the entire concentration range is misleading as concentrations $>20 \mathrm{ppbv}$ had to be removed due to saturation. It shows one of the best correlations with the average at the sub-10 ppbv comparison $\left(R^{2}=0.87\right.$, Table 2$)$.

Three instruments deployed here (DUAL-QCLAS, c-QCLAS and CIMS) have the potential to provide a fast $\mathrm{NH}_{3}$ spot measurement, of particular interest for aircraft applications and eddy-covariance flux measurements. Although their time response was not characterised here, they clearly provide faster response than the other instruments and previous characterisations has shown response times to be better than $1 \mathrm{~s}$, depending on inlet design (e.g. Whitehead et al., 2008).

The QCLAS technique (like OP-FTIR) in principle provides an absolute measurement of the concentration. However, without calibration, the instruments turned out to significantly underestimate the concentration. The c-QCLAS was calibrated at regular intervals in the field with a permeation tube calibration source, while a regular zero calibration but a one-off span calibration were applied to the DUALQCLAS, with average span calibration factors in the region of 1.3 and 1.2, for the two instruments respectively. This difference in the calibration approach is likely to be responsible for the poorer performance of the DUAL-QCLAS during this campaign. In addition, the DUAL-QCLAS was set up for eddy-covariance flux measurements, with a relatively long inlet, which may have added further uncertainty. The DUALQCLAS sampled air through a $2 \mathrm{~m}$ length of $6.4 \mathrm{~mm}$ PFA tubing. Owing to the "sticky" nature of $\mathrm{NH}_{3}$, this can have an impact on $\mathrm{NH}_{3}$ measurements (Shaw et al., 1998; Whitehead et al., 2008). This may therefore partly explain the under-estimate in the $\mathrm{NH}_{3}$ concentration at the peak concentrations. Against this possible argument, it should be noted that the DUAL-QCLAS showed one of the highest $R^{2}$ values ( 0.98 for the full dataset), with a small intercept compared with other instruments (Fig. 4d and Table 6), indicating a significant but rather constant slope of $\sim 1.2$. By contrast, the c-QCLAS was one the better performing instruments tested here.

The CIMS provides a fast, highly sensitive technique and this was the first field deployment of this particular instrument, which showed more scatter than most instruments. Although, it should be noted that it is uncertain how much of this scatter is natural variability and how much is represented by instrumental noise. The instrument was calibrated hourly and the sensitivity of the instrument was $(2.5 \pm 0.5)$ $\mathrm{Hz} \mathrm{ppt}^{-1} 1 \sigma$ and the $1 \sigma$ background noise corresponded to 45 pptv. In a subsequent deployment of this instrument (C. J. Percival, personal communication, 2009), which employed a similar inlet design and throughput, large variability in $\mathrm{NH}_{3}$ signal was observed on a second by second basis, such variability was not present in the background and calibration cycles, indicating that the inlet is able to respond to rapid changes in the $\mathrm{NH}_{3}$ concentration associated with different plumes and is therefore capturing real, rather than artificial variability. It appears that, as with the c-QCLAS approach, stability in the instrument response coupled with the need for a reliable zero and span gas-phase calibration source is the limiting factor in improving performance. This is consistent with the observations of Nowak et al. (2007), who reported the need for very frequent background determinations for an airborne CIMS instrument, especially when targeting background concentrations.

The OP-FTIR instrument averages over a path-length of $100 \mathrm{~m}$ which possibly limits comparability with the other point measurement techniques. Furthermore, measurements were made over a more limited concentration range. Yet, the comparison with the other fast-response techniques is encouraging (Fig. 5). Like the c-QCLAS, the OP-FTIR should also provide an absolute measurement but reports some of the lowest concentrations. At very low concentrations, instrument noise may exceed the signal from $\mathrm{NH}_{3}$, which may explain the high intercept ( $>3.74 \mathrm{ppbv}$ ) in comparison with other detection methods. Interestingly, both c-QCLAS and OP-FTIR underestimate the concentration when used in absolute (uncalibrated) mode and both rely on the accuracy of the same absorption line information of the HITRAN database.

All three wet chemistry systems used here are based on flow injection analysis using a selective ion membrane, which is known to have some cross sensitivity for some amines (Husted et al., 2000). Although probably unimportant here, they may make a more significant contribution in other situations, e.g. of organic animal manure emissions. Using batch sampling and off-line analysis, the RBD is the most "manual" technique included here. It is surprising that the RBD performed better (compared with the average) at small concentrations than over the entire concentration range (Table 2). This is possibly due to sample carry-over in situations of highly variable concentrations. AMANDA and AiRRmonia compared well with each other and, together with WaSul-Flux and IMS (and closely followed by c-QCLAS), achieved the best agreement with each other over the low concentration range. AMANDA and IMS read somewhat higher than the other instruments. The excellent agreement on the common liquid standard within $\pm 3 \%$ (Table 2) indicates that the wet chemistry instruments are stable and easy to calibrate, as long as the collection efficiency can be assumed to be $100 \%$ and the flow rates are well established. The wet chemistry instruments have the implicit advantage 
that they do not rely on an accurate gas-phase standard or any absorption cross sections. Further, they provide a more robust approach to separating gas and aerosol phase. However, they could potentially suffer artefacts from interfering gas-phase compounds in certain situations.

The WaSul-Flux instrument was compared against an AMANDA in previous measurement campaigns (Pogány et al., 2009), where a correlation coefficient of 0.98 was found between the photoacoustic signal and the concentration readings of AMANDA for concentrations 0 to $120 \mathrm{ppbv}$, which agrees with the correlation coefficients for $\mathrm{NH}_{3}$-ens in this campaign (0.98, Fig. 4f), and the correlation coefficients between WaSul-Flux and the wet-chemistry instruments $(0.98$ for AMANDA and AiRRmonia and 0.95 for the RBD; Table 5). However, the limit of detection of the WaSul-Flux instrument $(0.25 \mathrm{ppbv})$ is currently higher than that stated for the AMANDA (0.02 ppbv) or AiRRmonia (0.04 ppbv).

\subsection{Time responses}

The additional capture of $\mathrm{NH}_{3}$ variations of instruments with higher time resolution, shown in Sect. 3.1, is consistent with the observations of Norman et al. (2009). The calculated time response for the instruments in Sect. 3.3 showed higher values than stated by the manufacturers (Table 1). This is particularly true for the AMANDA system for which the actual response time was estimated to be $37 \mathrm{~min}$. A similar observation was made for the GRAEGOR analyser, based on the same horizontal annular denuder design, but using a lower liquid flow rate (Thomas et al., 2009). Faster response could be achieved by further minimising the liquid pool in the denuders, or by increasing the liquid flow rate (thereby sacrificing sensitivity). For the AiRRmonia, the calculated time response of $14.4 \pm 4.0 \mathrm{~min}$ time to obtain $95 \%$ of the signal is only slightly slower than the $10 \mathrm{~min}$ measurement cycle (Table 1). The same is true for CRDS and Nitrolux-100 with $13.4 \pm 5.0 \mathrm{~min}$ and $10.9 \pm 2.5 \mathrm{~min}$ to obtain $95 \%$ of the signal, respectively, as compared with instrument recording every $6 \mathrm{~s}$ (Table 1). During the study of Schwab et al. (2007), a TDLAS reached a value near $35 \mathrm{ppbv}$ within $6 \mathrm{~min}$, whereas IMS and Nitrolux-100 had the slowest time response of all the instruments investigated in their experiment. The same observations were made during this inter-comparison, where the IMS presented the slowest time response, probably due to the use of internal materials which are not optimised for $\mathrm{NH}_{3}$ measurements.

\section{Conclusions}

This paper reports an inter-comparison of eleven instruments for measuring atmospheric $\mathrm{NH}_{3}$ at ambient concentrations, representing the largest $\mathrm{NH}_{3}$ inter-comparison under typical field conditions to date. The approaches deployed included automated wet chemistry techniques, optical, photo-acoustic and mass spectrometric techniques. There were differences in the concentrations reported, but overall the high correlation with $R^{2}>0.84$ compared with the average of all instruments used, is very encouraging. The correlation worsens if only concentrations $<10 \mathrm{ppbv}$ are considered. Concentrations of RBD, AMANDA, AiRRmonia, WaSul-Flux and cQCLAS agreed within $\pm 25 \%$ for concentrations $>10$ ppbv. Some reasons for variability were identified: inlet length greatly affects measurement precision and time-response. Where used, inlet filters need to be changed very frequently (e.g. daily to weekly), at much shorter intervals than stated by some manufacturers. Instruments based on chemical ionisation mass spectroscopy and quantum cascade laser absorption spectroscopy need to be calibrated or at least zeroed frequently, and the provision of a reliable gas-phase calibration source in the field determines their measurement accuracy. Wet chemistry instruments show good long-term stability, are housed to operate with very short inlets and the liquid part of the system is easier to calibrate. They provide a reliable differentiation between gas-phase $\mathrm{NH}_{3}$ and aerosol $\mathrm{NH}_{4}^{+}$, which could not be validated for the other instruments during this study. For future inter-comparisons using all inlets at a single sampling point should be attempted, bearing in mind the logistic constraints when working with a large number of sizeable instruments. Not all instruments tested here are suitable for accurate measurements at concentrations $<1 \mathrm{ppbv}$, while the application of ion mobility spectroscopy is limited to low concentrations ( $<20$ ppbv) and conditions with no competing pollutants. Despite, recent advances in technologies, the continuous measurement of $\mathrm{NH}_{3}$ remains a challenging and costly enterprise, in terms of capital investment or running costs or both.

Acknowledgements. The measurements were supported by the UK Natural Environment Research Council (NERC) through grant nos. NE/E018505/1 and NE/E018092/1, the UK Department for Environment, Food and Rural Affairs and its devolved administrations through the Acid Deposition Processes Project and through the European Commission Integrated Project NitroEurope. The first author was recipient of exchange grant no. 2153 of the Nitrogen in Europe (NinE) project of the European Science Foundation. C. F. Braban gratefully acknowledges the loan of the CRDS and technical support from EnviroTechnology and Picarro. King's College London gratefully acknowledges the loan of equipment to carry out this research from the UK NERC Field Spectroscopy Facility.

Edited by: J. Stutz 


\section{References}

Asman, W. A. H., Sutton, M. A., and Schjorring, J. K.: Ammonia: emission, atmospheric transport and deposition, New Phytol., 139, 27-48, 1998.

Bacon, T., Webber, K., and Carpio, R. A.: Contamination monitoring for ammonia, amines, and acid gases utilizing ion mobility spectroscopy (IMS), Proc. SPIE-Int. Soc. Opt. Eng., Metrology, Inspection and Process Control for Microlithography XII, ISBN 0-8194-2777-2, 3332, 550-559, 1998.

Berden, G., Peeters, R., and Meijer, G.: Cavity ring-down spectroscopy: Experimental schemes and applications, Int. Rev. Phys. Chem., 19, 565-607, 2000.

Blatter, A., Neftel, A., Dasgupta, P. K., and Simon, P. K.: A combined wet effluent denuder and mist chamber system for deposition measurements of $\mathrm{NH}_{3}, \mathrm{NH}_{4}, \mathrm{HNO}_{3}^{-}$and $\mathrm{NO}_{3}$, in: Physicochemical Behaviour of Atmospheric Pollutants, edited by: Angeletti, G. and Restelli, G., European Commission, Brussels, 767-772, 1994.

Breitenbach, L. P. and Shelef, M.: Development of a method for the analysis of $\mathrm{NO}_{2}$ and $\mathrm{NH}_{3}$ by $\mathrm{NO}^{-}$measuring instruments, J. Air Pollut. Control Assoc., 23, 128-131, 1973.

Cantrell, C. A.: Technical Note: Review of methods for linear leastsquares fitting of data and application to atmospheric chemistry problems, Atmos. Chem. Phys., 8, 5477-5487, 2008, http://www.atmos-chem-phys.net/8/5477/2008/.

Cowen, K., Summer, A. L., Dindal, A., Riggs, K., Willenberg, Z., Hatfield, J., Pfeffer, R., and Scoggin, K.: Environmental Technology Verification Report. Pranalytica, Inc. Nitrolux 1000 Ambient $\mathrm{NH}_{3}$ Analyser, ETV, 2004.

Duyzer, J. H., Verhagen, H. L. M., Weststrate, J. H., Bosveld, F. C., and Vermetten, A. W. M.: The dry deposition of ammonia onto a Douglas fir forest in the Netherlands, Atmos. Environ., 29, 1241-1253, 1994.

Eden, P.: Weather log August 2008, R. Met. S., Weather, 63, 11, 322-348, doi:10.1002/wea.347, 2008.

Eiceman, G. A. and Karpas, Z.: Ion Mobility Spectrometry, CRC Press, Boca Raton, FL, 1994.

Erisman, J. W., Otjes, R., Hensen, A., Jongejan, P., van den Bulk, P., Khlystov, A., Moels, H., and Slanina, S.: Instrument development and application in studies and monitoring of ambient $\mathrm{NH}_{3}$, Atmos. Environ., 35, 1913-1922, 2001.

Fangmeier, A., Hadwiger-Fangmeier, A., van der Eerden, L., and Jäger, H.-J.: Effects of atmospheric ammonia on vegetation - a review, Environ. Pollut., 86, 43-82, 1994.

Fehsenfeld, F. C., Huey, L. G., Leibrock, E., Dissly, R., Williams, E., Ryerson, T. B., Norton, R., Sueper, D. T., and Hartsell, B.: Results from an informal intercomparison of ammonia measurement techniques, J. Geophys. Res., 107(D24), 4812, doi: 10.1029/2001JD001327, 2002.

Ferm, M.: Atmospheric ammonia and ammonium transport in Europe and critical loads: a review, Nutr. Cycl. Agroecosys., 51, 5-17, 1998.

Ferm, M.: Method for determination of atmospheric $\mathrm{NH}_{3}$, Atmos. Environ., 13, 1385-1393, 1979.

Gall, R., Perner, D., and Ladstatter-Weissenmayer, A.: Simultaneous determination of $\mathrm{NH}_{3}, \mathrm{SO}_{2}, \mathrm{NO}$ and $\mathrm{NO}_{2}$ by direct UVabsorption in ambient air, Fresen. J. Anal. Chem., 340, 646-649, 1991.
Galle, B., Bergquist, B., Ferm, M., Törnquist, K., Griffith, D. W. T., Jensen, N. O., and Hansen, F.: Measurement of ammonia emissions from spreading of manure using gradient FTIR techniques, Atmos. Environ., 34, 4907-4915, 2000.

Genfa, Z. and Dasgupta, P. K.: A Continuous Film-Recirculable Drop Gas-Liquid Equilibration Device. Measurement of Trace gaseous $\mathrm{NH}_{3}$, Anal. Chem., 72, 3165-3170, 2000.

Griffith, D. W. T. and Galle, B.: Flux measurements of $\mathrm{NH}_{3}$, $\mathrm{N}_{2} \mathrm{O}$ and $\mathrm{CO}_{2}$ using dual beam FTIR spectroscopy and the fluxgradient technique, Atmos. Environ., 34, 1087-1098, 2000.

Griffith, D. W. T.: Synthetic calibration and quantitative analysis of gas phase infrared spectra, Appl. Spectrosc., 50, 59-70, 1996.

Grisar, R., Preier, H., Schmidtke, G., and Restelli, G.: Monitoring of gaseous pollutants by tunable diode lasers, EC Air pollution Report 3, CEC, Brussels, Belgium, 1987.

Harren, F. J. M., Cotti, G., Oomens, J., and te Lintel Hekkert, S.: Photoacoustic Spectroscopy, in: Trace Gas Monitoring, Encyclopedia of Analytical Chemistry, edited by: Meyers, R. A., John Wiley \& Sons Ltd, Chichester, 2203-2226, 2000.

Hill Jr., H. H., Slems, W. F., St. Louis, R. H., and McMinn, D. G.: Ion Mobility Spectrometry, Anal. Chem., 62, 1201A-1209A, 1990.

Husted, S., Hebbern, C. A., Mattsson, M., and Schjoerring, J. K.: A critical experimental evaluation of methods for determination of $\mathrm{NH}_{4}^{+}$in plant tissue, xylem sap and apoplastic fluid, Physiol. Plant., 109, 167-179, 2000.

Janson, R., Rosman, K., Karlsson, A., and Hansson, H.-C.: Biogenic emissions and gaseous precursors to forest aerosols, Tellus, 53B, 423-440, 2001.

Keuken, M. P., Schoonebeek, C. A. M., van Wensveen-Louter, A., and Slanina, J.: Simultaneous sampling of $\mathrm{NH}_{3}, \mathrm{HNO}_{3}, \mathrm{HCl}$, $\mathrm{SO}_{2}$ and $\mathrm{H}_{2} \mathrm{O}_{2}$ in ambient air by wet annular denuder system, Atmos. Environ., 22, 2541-2548, 1988.

Kim, S., Huey, L. G., Stickel, R. E., Tanner, D. J., Crawford, J. H., Olson, J. R., Chen, G., Brune, W. H., Ren, X., Lesher, R., Wooldridge, P. J., Bertram, T. H., Perring, A., Cohen, R. C., Lefer, B. L , Shetter, R. E., Avery, M., Diskin, G., and Sokolik, I.: Measurement of $\mathrm{HO}_{2} \mathrm{NO}_{2}$ in the free troposphere during the intercontinental chemical transport experiment - North America 2004, J. Geophys. Res., 112, D12S01, doi:10.1029/2006JD007676, 2007.

Krupa, S. V.: Effects of atmospheric ammonia $\left(\mathrm{NH}_{3}\right)$ on terrestrial vegetation: a review, Environ. Pollut., 124, 179-221, 2003.

Lammel, G.: Determination of $\mathrm{NH}_{3}$ and nitric acid using a diffusion denuder method, Fresen. J. Anal. Chem., 340, 684-686, 1991.

Langford, A. O., Goldan, P. D., and Fehsenfeld, F. C.: A Molybdenum Oxide Annular Denuder System for Gas Phase Ambient $\mathrm{NH}_{3}$ Measurements, J. Atmos. Chem., 8, 359-376, 1989.

Marcy, T. P., Gao, R. S., Northway, M. J., Popp, P. J., Stark, H., and Fahey, D. W.: Using chemical ionization mass spectrometry for detection of $\mathrm{HNO}_{3}, \mathrm{HOl}$, and $\mathrm{ClONO}_{2}$ in the atmosphere, Int. J. Mass Spectrom., 243, 63-70, 2005.

McManus, J. B., Nelson, D. D., Shorter, J. H., Zahniser, M. S., Mueller, A., Bonetti, Y., Beck, M., Hofstetter, D., and Faist, J.: Quantum cascade lasers for open- and closed-path measurement of trace gases, in: Diode lasers and applications in atmospheric sensing, edited by: Fried, A., Proc. SPIE 4817, 22-33, 2002. 
McManus, J. B., Shorter, J. H., Nelson, D. D., and Zahniser, M. S.: Sensors Compact Quantum Cascade Laser Instrument for Rapid, High Sensitivity Measurements of Trace Gases in Air, Sensors, 2007 IEEE, 1341-1344, 2007.

Mennen, M. G., van Elzakker, B. G., van Putten, E. M., Uiterwijk, J. W., Regts, T. A., van Hellenmond, J., Wyer, G. P., Otjes, R. P., Verhage, A. J. L., Wouters, L. W., Heffels, C. J. G. Roemer, F. G., van den Beld, L., and Tetteroo, J. E. H.: Evaluation of automatic ammonia monitors for application in an air quality monitoring network, Atmos. Environ., 30, 3239-3256, 1996.

Milford, C., Sutton, M. A., Allen, A. G., Karlsson, A., Davison, B. M., James, J. D., Rosman, K., Harrison, R. M., and Sape, J. N.: Marine and land-based influence on atmospheric ammonia and ammonium over Tenerife, Tellus B, 52, 273-289, 2000.

Milford, C., Theobald, M. R., Nemitz, E., and Sutton, M.: Dynamics of $\mathrm{NH}_{3}$ exchange in response to cutting and fertilising an intensively-managed grassland, Water, Air, Soil Pollut., 1, 167 176, 2001.

Milford, C., Theobald, M. R., Nemitz, E., Hargreaves, K. J., Horvath, L., Raso, J., Dämmgen, U., Neftel, A., Jones, S. K., Hensen, A., Loubet, B., Cellier, P., and Sutton, M. A.: Ammonia fluxes in relation to cutting and fertilization of an intensively managed grassland derived from an inter-comparison of gradient measurements, Biogeosciences, 6, 819-834, 2009, http://www.biogeosciences.net/6/819/2009/.

Mozurkewich, M.: The Dissociation-Constant of AmmoniumNitrate and Its Dependence on Temperature, Relative-Humidity and Particle-Size, Atmos. Environ., 27, 261-270, 1993.

Myles, L., Meyers, T. P., and Robinson, L.: Atmospheric $\mathrm{NH}_{3}$ measurement with an ion mobility spectrometer, Atmos. Environ., 40, 5745-5752, 2006.

Neuman, J. A., Parrish, D. D., Trainer, M., Ryerson, T. B., Holloway, J. S., Nowak, J. B., Swanson, A., Flocke, F., Roberts, J. M., Brown, S. S., Stark, H., Sommariva, R., Stohl, A., Peltier, R., Weber, R., Wollny, A. G., Sueper, D. T., Hubler, G., and Fehsenfeld, F. C.: Reactive nitrogen transport and photochemistry in urban plumes over the North Atlantic Ocean, J. Geophys. Res., 111, D23S54, doi:10.1029/2005JD007010, 2006.

Norman, M., Hansel, A., and Wisthaler, A.: $\mathrm{O}^{2+}$ as reagent ion in the PTR-MS instrument: detection of gas-phase ammonia, Intern. J. Mass Spectrom., 265, 382-287, 2007.

Norman, M., Spirig, C., Wolff, V., Trebs, I., Flechard, C., Wisthaler, A., Schnitzhofer, R., Hansel, A., and Neftel, A.: Intercomparison of ammonia measurement techniques at an intensively managed grassland site (Oensingen, Switzerland), Atmos. Chem. Phys., 9, 2635-2645, 2009,

http://www.atmos-chem-phys.net/9/2635/2009/.

Nowak, J. B., Huey, L. G., Russell, A. G., Tian, D., Neuman, J. A., Orsini, D., Sjostedt, S. J., Sullivan, A. P., Tanner, D. J., Nenes, A., Edgerton, E., and Fehsenfeld, F. C.: Analysis of urban gas phase ammonia measurements from the 2002 Atlanta Aerosol Nucleation and Real-Time Characterization Experiment (ANARChE), J. Geophys. Res., 111, D17308, doi:10.1029/2006JD007113, 2006.

Nowak, J. B., Neumann, J. A., Kozai, K., Huey, L. G., Tanner, D. J., Holloway, J. S., Ryerson, T. B., Frost, G. J., McKeen, S. A., and Fehsenfeld, F. C.: A chemical ionization mass spectrometry technique for airborne measurements of $\mathrm{NH}_{3}$, J. Geophys. Res., 112, D10S02, doi:10.1029/2006JD007589, 2007.
Pogány, A., Mohácsi, Á., Varga, A., Bozóki, Z., Galbács, Z., Horváth, L., and Szabó, G.: A compact $\mathrm{NH}_{3}$ detector with subppb accuracy using near-infrared photoacoustic spectroscopy and preconcentration sampling, Environ. Sci. Technol., 43, 826-830, 2009.

Pushkarsky, M. B., Webber, M. E., and Patel, C. K. N.: Ultrasensitive ambient ammonia detection using $\mathrm{CO}_{2}$ laser-based photoacoustic spectroscopy, Appl. Phys. B-Lasers O., 77, 381-385, 2003.

Pushkarsky, M. B., Webber, M. E., Baghdassarian, O., Narasimhan, L. R., and Patel, C. K. N.: Laserbased photoacoustic ammonia sensor for industrial applications, Appl. Phys. B-Lasers O. special issue: Trends in Laser Sources, Spectroscopic Techniques and Their Applications to Trace Gas Detection, 75, 391-396, 2002.

Rella, C.: Picarro's $\mathrm{NH}_{3}$ analyzer for Ambient Air Monitoring, 6. Nationales $\mathrm{NH}_{3}$-Treffen. Hannover, Deutschland, 19/20 November, 2008.

Rothmann, L. S., Rinsland, C. P., Goldman, A., Massie, S. T., Edwards, D. P., Flaud, J. M., Perrin, A., Camy-Peyret, C., Danna, V., Mandin, J. Y., Schroeder, J., McCann, A., Gamache, R. R., Wattson, R. B., Yoshino, K., Chance, K. V., Jucks, K. W., Brown, L. R., Nemtchinov, V., and Varanasi, P.: The HITRAN molecular spectroscopic database and HAWKS (HITRAN atmospheric workstation), 1996 Ed., J. Quant. Spectrosc. Ra., 60, 665-710, 1998.

Schwab, J. J., Li, Y., Bae, M.-S., Demerjian, K. L., Hou, J., Zhou, X., Jensen, B., and Pryor, S. C.: A laboratory intercomparison of real-time gaseous ammonia measurement methods, Environ. Sci. Technol., 41, 8412-8429, 2007.

Shaw, W. J., Spicer, C. W., and Kenny, D. V.: Eddy correlation fluxes of trace gases using a tandem mass spectrometer, Atmos. Environ., 32, 2887-2898, 1998.

Simon, P. K. and Dasgupta, P. K.: Wet effluent denuder coupled liquid/ion chromatography systems: annular and parallel plate denuders, Anal. Chem., 65, 1134-1139, 1993.

Simon, P. K., Dasgupta, P. K., and Vecera, Z.: Wet effluent denuder coupled liquid/ion chromatography systems, Anal. Chem., 63 , 1237-1242, 1991

Slusher, D. L., Pitteri, S. J., Haman, B. J., Tanner, D. J., and Huey, L. G.: A chemical ionization technique for measurement of pernitric acid in the upper troposphere and the polar boundary layer, Geophys. Res. Lett., 28, 3875-3878, 2001.

Sunner, J., Nicol, G., and Kebarle, P.: Factors Determining Relative Sensitivity of Analytes in Positive Mode Atmospheric-Pressure Ionization Mass-Spectrometry, Anal. Chem., 60, 1300-1307, 1988.

Sutton, M., Fowler, D., Burkhardt, J. K., and Milford, C.: Vegetation atmosphere exchange of ammonia: canopy cycling and the impacts of elevated nitrogen inputs, Water,Air Soil Poll., 85, 2057-2063, 1995.

Sutton, M. A., Nemitz, E., Milford, C., Fowler, D., Moreno, J., San Jose, R., Wyers, G. P., Otjes, R. P., Harrison, R., Husted, S., and Schjoerring, J. K.: Micrometeorological measurement of net $\mathrm{NH}_{3}$ fluxes over oilseed rape during two vegetation periods, Agric. For. Meteorol., 105, 351-369, 2000a. 
Sutton, M. A., Dragosits, U., Tang, Y. S., and Fowler D.: Ammonia emissions from non agricultural sources in the UK, Atmos. Environ., 34, 855-869, 2000b.

Sutton, M. A., Tang, Y. S., Dragosits, U., Fournier, N., Dore, T., Smith, R. I., Weston K. J., and Fowler D.: A spatial analysis of atmospheric ammonia and ammonium in the UK, The Scientific World 1 (S2), 275-286, 2001.

Sutton, M. A., Nemitz, E. , Erisman, J. W., Beier, C., Butterbach Bahl, K., Cellier, W. de Vries, P., Cotrufo, F., Skiba, U., Di Marco, C., Jones, S., Laville, P., Soussana, J. F., Loubet, B., Twigg, M., Famulari, D., Whitehead, J., Gallagher, M. W., Neftel, A., Flechard, C. R., Herrmann, B., Calanca, P. L., Schjoerring, J. K., Daemmgen, U., Horvath, L., Tang, Y. S., Emmett, B. A., Tietema, A., Peñuelas, J., Kesik, M., Brueggemann, N., Pilegaard, K., Vesala, T., Campbell, C. L., Olesen, J. E., Dragosits, U., Theobald, M. R., Levy, P., Mobbs, D. C., Milne, R., Viovy, N., Vuichard N., Smith, J. U., Smith, P., Bergamaschi, P., Fowler, D., and Reis, S.: Challenges in quantifying biosphereatmosphere exchange of nitrogen species, Environ. Pollut., 150, 125-139, 2007.

Thomas, R. M., Trebs, I., Otjes, R., Jongejan, P. A. C., ten Brink, H., Phillips, G., Kortner, M., Meixner, F. X., and Nemitz, E.: An automated analyzer to measure surface-atmosphere exchange fluxes of water soluble inorganic aerosol compounds and reactive trace gases, Environ. Sci. Technol., 43(5), 1412-1418, 2009.

Tittel, F. K., Richter, D., and Fried, A.: Mid-infrared laser applications in spectroscopy, in: Topics in Applied Physics vol. 89, edited by: Sorokina, I. T. and Vodopyanov, K. L., SpringerVerlag, 445-516, 2003.

Warland, J. S., Dias, G. M., and Thurtell, G. W.: A tunable diode laser system for ammonia flux measurement over multiple plots, Environ. Pollut., 114, 215-221, 2001

Warneck, P.: Chemistry of the Natural Atmosphere, Academic Press, New York, 1988.
Wert, B. P., Fried, A., Henry, B., and Cartier, S.: Evaluation of inlets used for the airborne measurement of formaldehyde, J. Geophys. Res., 107(D13), 4163, doi:10.1029/2001JD001072, 2002.

Whitehead, J. D., Longley, I. D., and Gallagher, M. W.: Seasonal and diurnal variation in atmospheric $\mathrm{NH}_{3}$ in an urban environment measured using a quantum cascade laser absorption spectrometer, Water Air Soil Pollut., 183, 317-329, 2007.

Whitehead, J. D., Twigg, M., Famulari, D., Nemitz, E., Sutton, M. A., Gallagher, M. W., and Fowler, D.: Evaluation of Laser Absorption Spectroscopic Techniques for Eddy Covariance Flux Measurements of $\mathrm{NH}_{3}$, Environ. Sci. Technol., 42, 2041-2046, 2008.

Wiebe, H. A., Anlauf, K. G., Tuazon, E. C., Winer, A. M., Biermann, H. W., Appel, B. R., Solomon, P. A., Cass, G. R., Ellestad, T. G., Knapp, K. T., Peake, E., Spicer, C. W., and Lawson, P. A.: A comparison of measurements of atmospheric ammonia by filter packs, transition-flow reactors, simple and annular denuders and Fourier-Transform Infrared-Spectroscopy, Atmos. Environ. A-Gen., 1019-1028, 1990.

Williams, E. J., Sandholm, S. T., Bradshaw, J. D., Schendel, J. S., Langford, A. O., Quinn, P. K., LeBel, P. J., Vay, S. A., Roberts, P. D., Norton, R. B., Watkins, B. A., Buhr, M. P., Parrish, D. D., Calvert, J. G., and Fehsenfeld, F. C.: An intercomparison of five ammonia measurement techniques, J. Geophys. Res., 97, 591$611,1992$.

Wyers, G. P., Otjes, R. P., and Slanina, J.: A continious flow denuder for the measurement of ambient concentrations and surface fluxes of $\mathrm{NH}_{3}$, Atmos. Environ., 27A, 2085-2090, 1993.

Yokelson, R. J., Christian, T. J., Bertschi, I. T., and Hao, W. M. Evaluation of adsorption effects on measurements of ammonia, acetic acid and methanol, J. Geophys. Res., 108, 46-49, 2003. 